\title{
21. VOLCANOGENIC SEDIMENTS AND THEIR RELATION TO LANDMASS VOLCANISM AND SEA FLOOR-CONTINENT MOVEMENTS, WESTERN INDIAN OCEAN, LEG 25, DEEP SEA DRILLING PROJECT
}

\author{
T. L. Vallier, Scripps Institution of Oceanography, La Jolla, California
}

\begin{abstract}
Volcanic activity is recorded in sediments from eight sites in the western Indian Ocean. Sediments that are notably volcanogenic occur in the Lower Cretaceous at Site 249 (Mozambique Ridge), in the Paleocene at Site 245 (Madagascar Basin), and in the Eocene at Sites 246 (Madagascar Ridge) and 248 (Mozambique Basin). Volcanogenic sediments also are in the Upper Cretaceous at Site 241 (western Somali Basin), and at Site 239 (Mascarene Basin) where they are irregularly dispersed through the sediment column.

Times of volcanism in eastern Africa, Madagascar, parts of India, and the Comoro and Mascarene Islands correlate quite well with ages of the above volcanic sediments. These correlations show that in the western Indian Ocean area, significant volcanic activity occurred in Early Cretaceous, Late Cretaceous (mostly Campanian), Paleocene, Eocene, and Miocene-Recent times.

Uppermost Jurassic volcanism in eastern Africa, and Early Cretaceous volcanism in eastern Africa, Madagascar, India, and on the Mozambique Ridge (Site 249) may signify the first major tensional tectonic events in the breaking up of Gondwana. Campanian volcanism certainly marks a major event, in view of the great outpourings of lava which took place on Madagascar and the high rates of sea floor movements (high spreading rate) that began at anomaly 30 and continued through anomaly 27 . Paleocene volcanism occurred in India (Deccan Basalt), in northern Madagascar, and along the Central Indian Ridge (Site 245). Eocene volcanic sediments at Sites 246 and 248 apparently are related to Madagascar Ridge volcanism and possibly to changes in sea floor movements. Small intrusives in Madagascar mark other Eocene igneous events. Miocene to Recent volcanic activity has taken place on the Comoro and Mascarene islands, along the East African rift system, and in northern Madagascar. However, this phase of volcanism is mostly masked in the deep sea deposits of the western Indian Ocean by high quantities of terrigenous and biogenous sediments.
\end{abstract}

\section{INTRODUCTION}

The distribution of volcanogenic sediments in the western Indian Ocean is dependent on the time and space relationships of continental, island, and submarine volcanism, on submarine barriers to sediment transport, and on winds and ocean currents (surface and deep). It is the major purpose of this paper to describe the stratigraphic relationships of volcanogenic sediments that were drilled during Leg 25 (Figure 1) and to determine the origins and subsequent histories of those sediments. A secondary purpose is to relate the major volcanic events in the western Indian Ocean basin and on adjacent landmasses to other major events, e.g., sea floor-continent movements, that have occurred.
Data were derived from core and smear slide descriptions, X-ray diffraction results, grain-size and carbon-carbonate analyses, and studies of 24 thin sections. Some chemical analyses of sediments were completed by Marchig for Sites 248 and 249 (Marchig and Vallier, this volume) and by Warner and Gieskes (this volume) for Site 245.

Fresh volcanogenic sediments are either rare or absent in most holes. Because most are altered, the original volcanic nature of the sediments is deduced from lithologic relationships, from clay mineral compositions, and from the presence of authigenic minerals which infer a volcanic origin.

The best evidence for volcanic origin of sediments is the presence of volcanic rock fragments, volcanic minerals, glass 


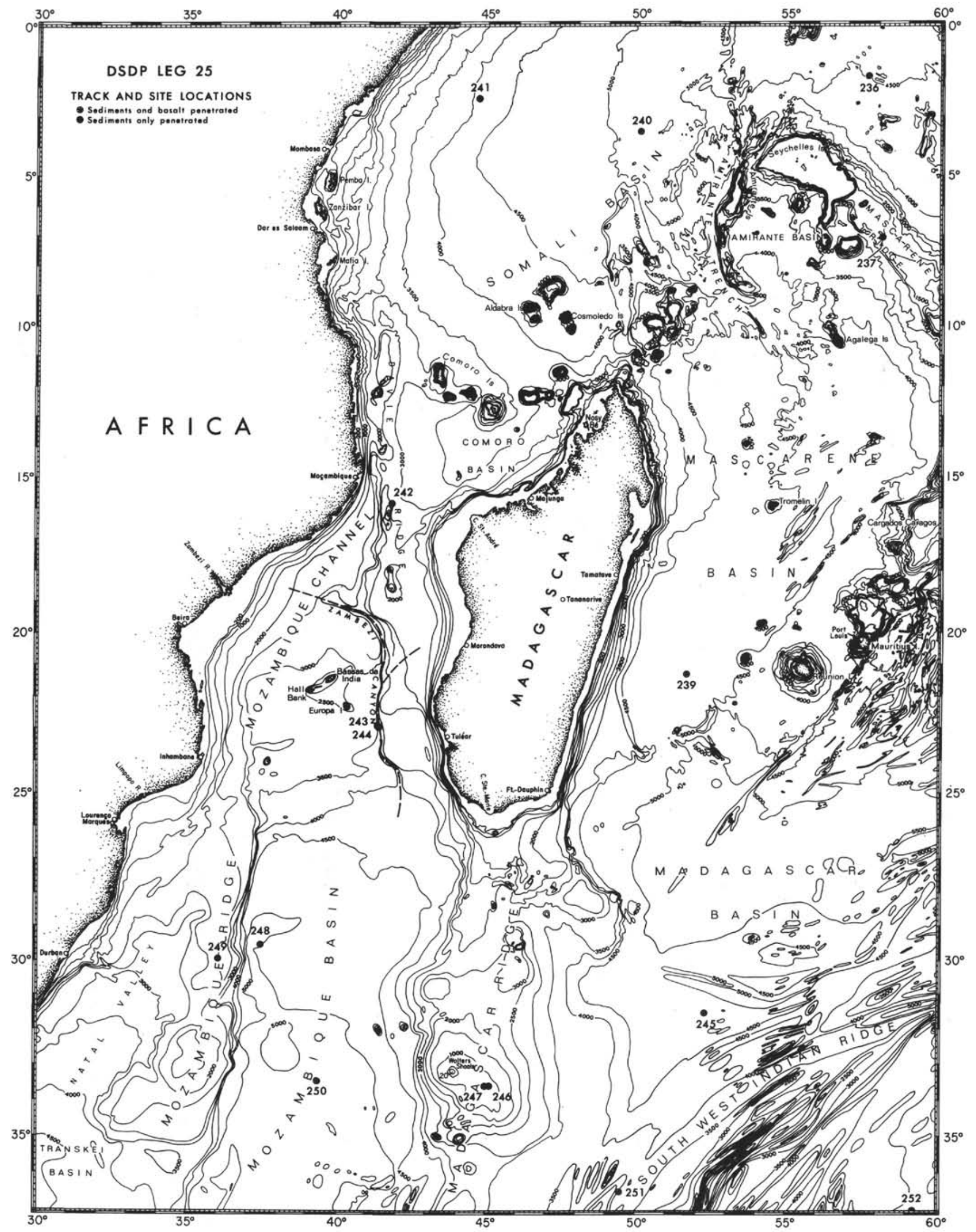

Figure 1. Index map of the western Indian Ocean showing Leg 25 Sites. 
shards, and their alteration products. In completely altered marine volcanic sediments, color and textural changes can sometimes be used to distinguish them from other sediments. Also, particularly in clay-rich chalk and ooze, the presence of sharp basal contacts of beds and gradational, heavily-burrowed upper contacts suggest a volcanic influence.

Clay mineralogies of the sediments, as determined by X-ray diffraction analyses of the carbonate-free, $<2 \mu$ size fraction may suggest a volcanic origin. The conclusions of Griffin et al. (1968) are used in this report to determine clay mineral origins. In general, kaolinite, chlorite, and illite-mica reflect nonvolcanic terrestrial (continental) contributions, whereas the montmorillonite group (smectite family) reflects a volcanic origin. Montmorillonite clays are believed to originate from the alteration of volcanic materials and either can form subaerially and be transported to the ocean for subsequent dispersal or can form authigenically on the sea floor.

The clay mineral palygorskite is nearly ubiquitous in sediments from holes drilled on Leg 25. Both its X-ray identification (Zemmels and Cook, 1973, p. 605) and the interpretations of its possible origins (see, for example, Hathaway and Sachs, 1965; Siever and Kastner, 1967; Bonatti and Joensuu, 1968; Millot et al., 1969; Hathaway et al., 1970; and Berger and von Rad, 1972) are not agreed upon. This clay mineral, more properly called attapulgite, is formed in both continental and marine environments, but it generally is the result of an authigenic change that may be depth dependent in a sediment column. In sediments recovered on Leg 25 , there is no consistent relationship of palygorskite in time and space. In some holes, it is associated only with montmorillonite and thus seems to be a final product of the diagenesis of fine-grained volcanogenic sediments. In other holes, there seems to be no correlation between palygorskite and montmorillonite, thereby suggesting that it was eroded from surrounding landmasses or that it was derived in situ from nonvolcanic and/or volcanic materials.

In cored intervals where palygorskite and montmorillonite are the only clay minerals present, it is inferred that palygorskite was derived from the alteration of volcanic material and, therefore, has the same origin as the montmorillonite. If the other major layered silicates, chlorite, kaolinite, and/or illite-mica are present in significant amounts (generally more than $10 \%$ of the total clay fraction), it is inferred that there was a significant nonvolcanic continental (or terrestrial) influence and that the volcanic materials (mostly montmorillonite) may be detrital in part. Although this boundary is artificial, it does form a framework in which to evaluate the various clay contributions.

Zeolites, particularly phillipsite and clinoptilolite, are often considered to be authigenic products of altered volcanic materials. This statement is particularly true of phillipsite (Arrhenius, 1963). Clinoptilolite is believed to form in the marine environment by the reaction of magnesium-rich solutions with volcanic glass or with minerals of the smectite family (Bonatti, 1972). The presence of that zeolite in carbonate and siliceous oozes suggests that it also can form in sediments which lack volcanic detritus. However, in most samples studied from Leg 25 sediments, the only clay minerals associated with clinoptilolite are montmorillonite and palygorskite, which thereby suggests an association of clinoptilolite with altered volcanic sediments.

In summary, if lithologic and stratigraphic evidences of volcanic materials are missing, the presence either of montmorillonite or of montmorillonite plus palygorskite in the $<2 \mu$ size fraction, in the absence or near absence of the other clay minerals, is used to infer a volcanic origin for that clay-sized fraction. Zeolites also suggest the original presence of volcanic material.

\section{VOLCANOGENIC SEDIMENTS AT LEG 25 SITES}

In this section, the locations, sediment characteristics, and direct and inferred evidences for volcanogenic sediments are described for the sites. Because sediment recovery was very small at Sites 243,244 , and 247 , only Sites $239,240,241,242,245,246,248$, and 249 are discussed. Figures accompanying the individual site descriptions (Figures 2-6, 11, 16, and 18) show relative amounts of volcanic contributions at each site, where $\mathrm{R}=\mathrm{Rare}$ (only a small amount, generally as montmorillonite); $\mathrm{C}=\mathrm{Common}$ (noticeable ash beds in sediments and/or high montmorillonite content); and $\mathrm{A}=\mathrm{Abundant}$ (volcanic tuff or volcanic epiclastic sediments comprise most of the unit). Also included in the figures are stratigraphic units, lithologies, geologic ages, $\mathrm{CaCO}_{3}$ contents, and relative percentages of clay minerals in the $<2 \mu$ size fraction.

\section{Site 239}

Site 239 is located in the southern part of the Mascarene Basin between Madagascar and the Southwest Indian Ridge. The sediments are divided into two major units overlying an extrusive basalt "basement" (Figure 2). Unit I, middle Miocene to Quaternary in age, consists mostly of silty clay and clay-rich nanno ooze; minor lithologies are nannobearing clay, foram-rich nanno ooze, and foram/carbonaterich nanno ooze. Unit II, Late Cretaceous to middle Miocene in age, is made up of brown clay and brown silty clay.

In Unit I (Cores 1-10), some volcanic materials are present in the sediments. Glass shards and rare pumice fragments are direct evidence, whereas high montmorillonite content and the occurrence of phillipsite infer the presence of volcanic materials. One X-ray sample, 3-3, $65-67 \mathrm{~cm}$, consists mostly of montmorillonite, with plagioclase, phillipsite, potash feldspar, augite(?), and calcite as the other major contributors. Undoubtedly, this is a devitrified volcanic ash which probably has a small amount of nonvolcanic terrigenous sediment included. Other ash beds may be present but are masked by the nonvolcanic terrigenous and biogenic sediments.

In Unit II (Cores 11-19), evidence for volcanic materials in the brown clay and brown silty clay sequence includes the presence of light brown devitrified volcanic ash beds and an abundance of montmorillonite. Although mechanical deformation and relatively poor recovery hinders the 


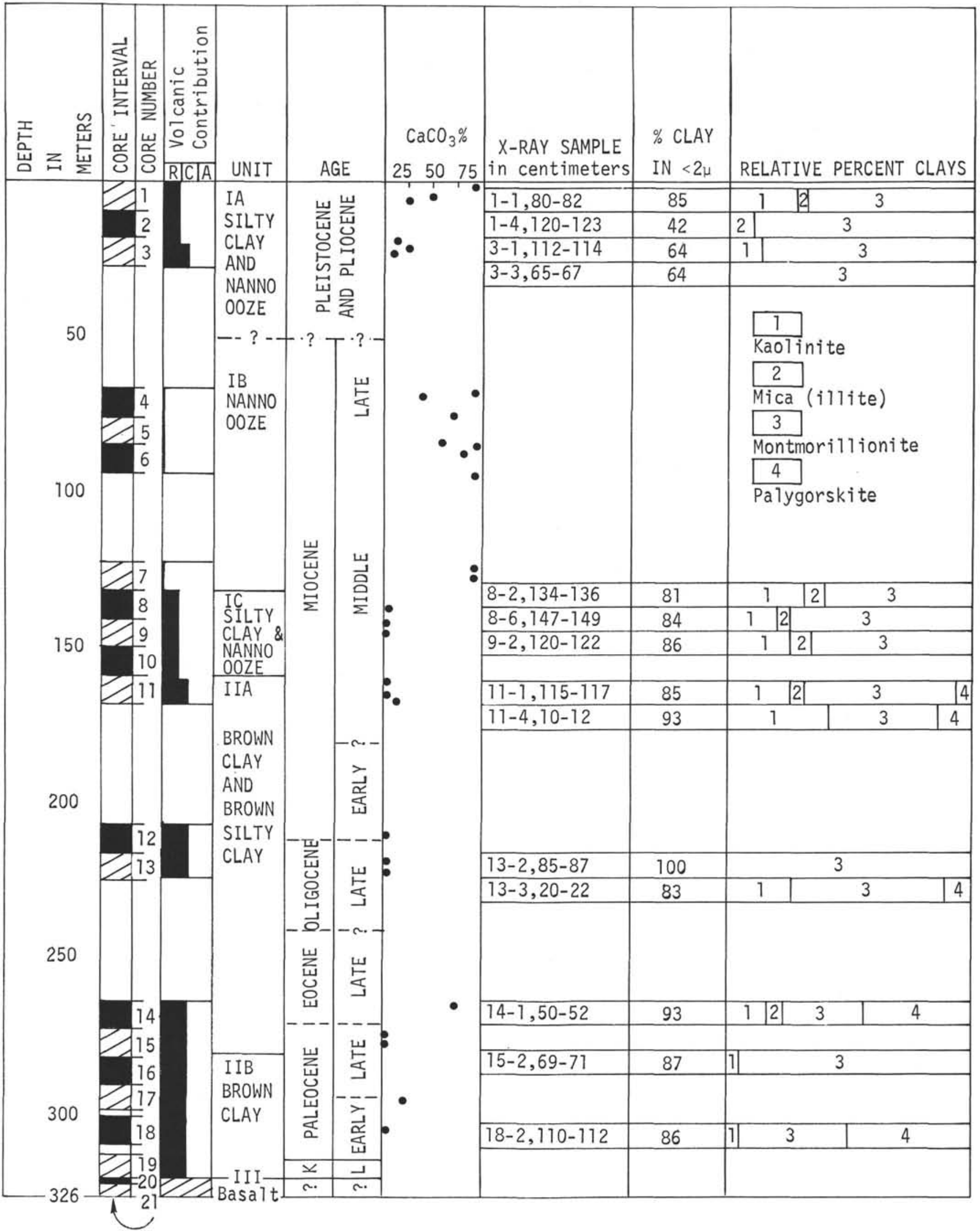

Figure 2. Volcanogenic sediments, Site 239, with $\mathrm{CaCO}_{3}$ and clay percentages. Dashed lines in "age" column signify uncertain boundaries. In "volcanic contributions" column, $\mathrm{R}=$ rare, $\mathrm{C}=$ common, and $\mathrm{A}=$ abundant (see text for explanation). 
estimation of ash abundance, several discrete devitrified ash beds do occur in the sequence. Palygorskite, which occurs only in Unit II at Site 239, probably formed contemporaneously with montmorillonite and might be considered as indirect evidence for the presence of volcanic additions.

\section{Site 240}

Site 240 is located in the eastern part of Somali Basin. Two holes were drilled, Holes 240 and 240A, and 12 cores were attempted (Figure 3). Drilling disturbance and poor recovery greatly handicapped stratigraphic and paleontologic studies (see Chapter 3, this volume). Sediment ages range from early Eocene to Quaternary. However, biostratigraphic conclusions were difficult to arrive at and are somewhat tenuous because fauna and flora of mixed ages were found in many of the samples. This condition was caused both by initial mixing during sedimentation and by mechanical mixing during coring.

Sediments are divided into two major units which overlie extrusive basalt. The upper unit (Unit I) consists of nanno/rad ooze, silty clay, and clayey silt; the lower unit
(Unit II) has nanno ooze, silty clay, silt, and sand. The occurrence of rare volcanic glass shards is the only direct evidence in the sediment of volcanic contributions. The abundance of montmorillonite and palygorskite in the clay fractions infers some volcanic influence. However, it can be concluded that volcanism had a volumetrically small effect on the sediment column at this site.

\section{Site 241}

Site 241 is located on the lower part of the East Africa continental rise in the western part of Somali Basin where the sediment thickness is about $3 \mathrm{sec}$ double time (DT). Acoustic basement was not penetrated at this site. Twenty-nine cores were cut, and the sediment column was divided into two units. Unit I (Cores 1-16), late Oligocene to Quaternary in age, is clay and clay-rich nanno ooze, Unit II (Cores 17-29), early Senonian to middle Eocene in age, consists of clay/claystone and silty claystone.

The contributions of nonvolcanic terrigenous material to the sediments are emphasized by Moore (this volume), who concludes that because of the abundance of potash feldspar

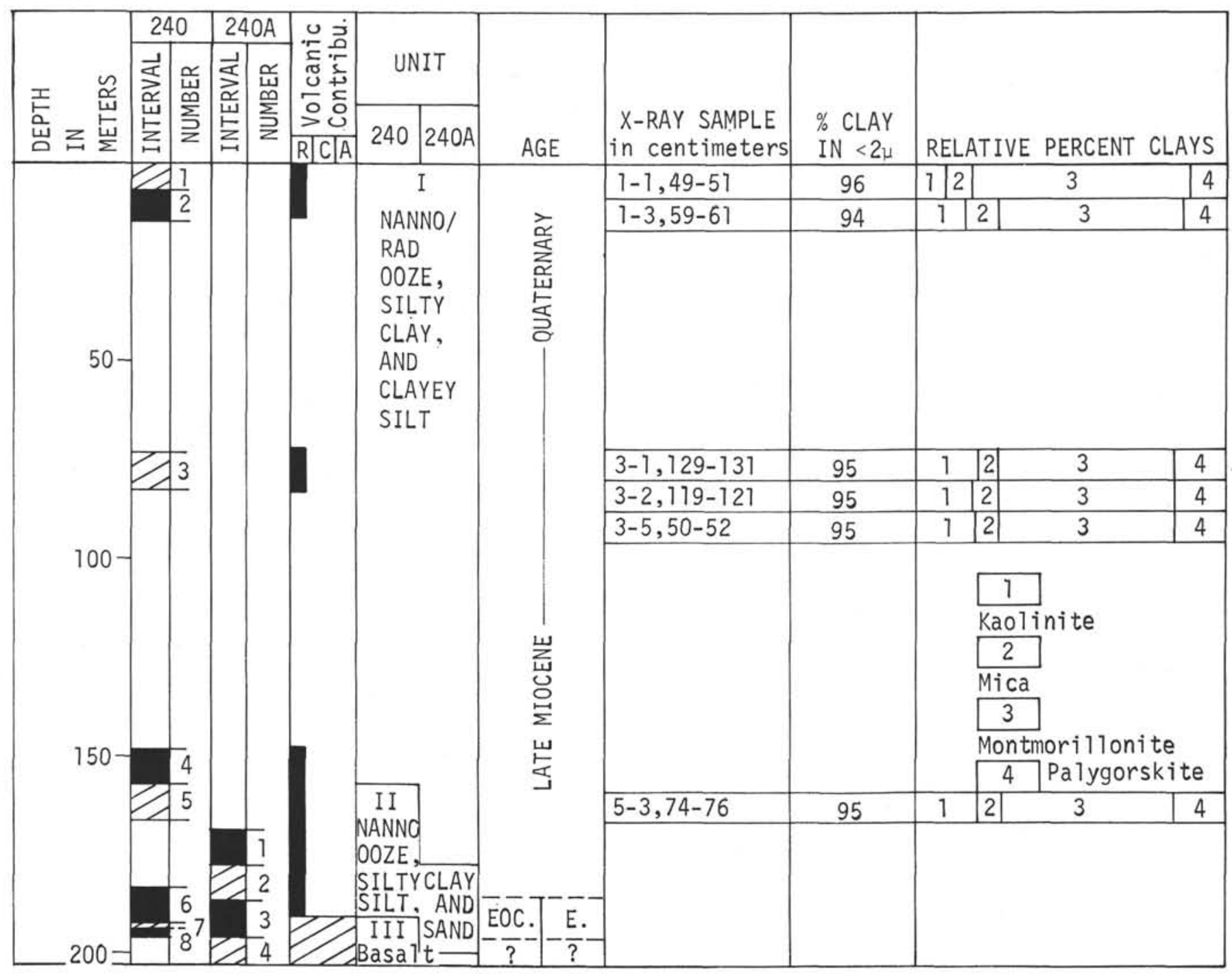

Figure 3. Volcanogenic sediments, Holes 240 and 240A, with clay percentages. Dashed lines in "age" column signify uncertain boundaries. In "volcanic contributions" column, $\mathrm{R}=$ rare, $\mathrm{C}=$ common, and $\mathrm{A}=$ abundant. 
and diagnostic heavy minerals, most nonbiogenic material was derived from the continent. Some volcanic materials also are present in the sediments (Figure 4). Direct evidence includes the presence of glass shards in Cores 1-11 and Core 15 , plus devitrified ash beds, mostly $5-10 \mathrm{~cm}$ thick, in Cores $7,15,16,20,25$, and 28. Particularly noticeable in Unit II are dark brown, intensely burrowed zones which suggest that thin layers of nutrient-rich volcanic ash had been reworked by benthonic organisms. The abundance of montmorillonite, and possibly palygorskite, also infers volcanic contributions.

\section{Site 242}

Site 242 is located on the eastern flank of Davie Ridge in the Mozambique Channel between Madagascar and eastern Africa. Three sedimentary units are recognized, which range in age from late Eocene to Recent. Unit I (Cores 1-5), of late Miocene to Recent age, is a foram-bearing to foram-rich nanno ooze. Unit II (Cores 5-7), mostly of middle and late Miocene age, is a foram-bearing clayey nanno chalk, and Unit III (Cores 8-19), of late Eocene to middle Miocene age, is a brown clayey nanno chalk.

This site has been within a pelagic sedimentation realm, at least since the late Eocene, and bottom conditions have remained essentially unchanged. Volcanic contributions are very minor and can be inferred only from the indirect

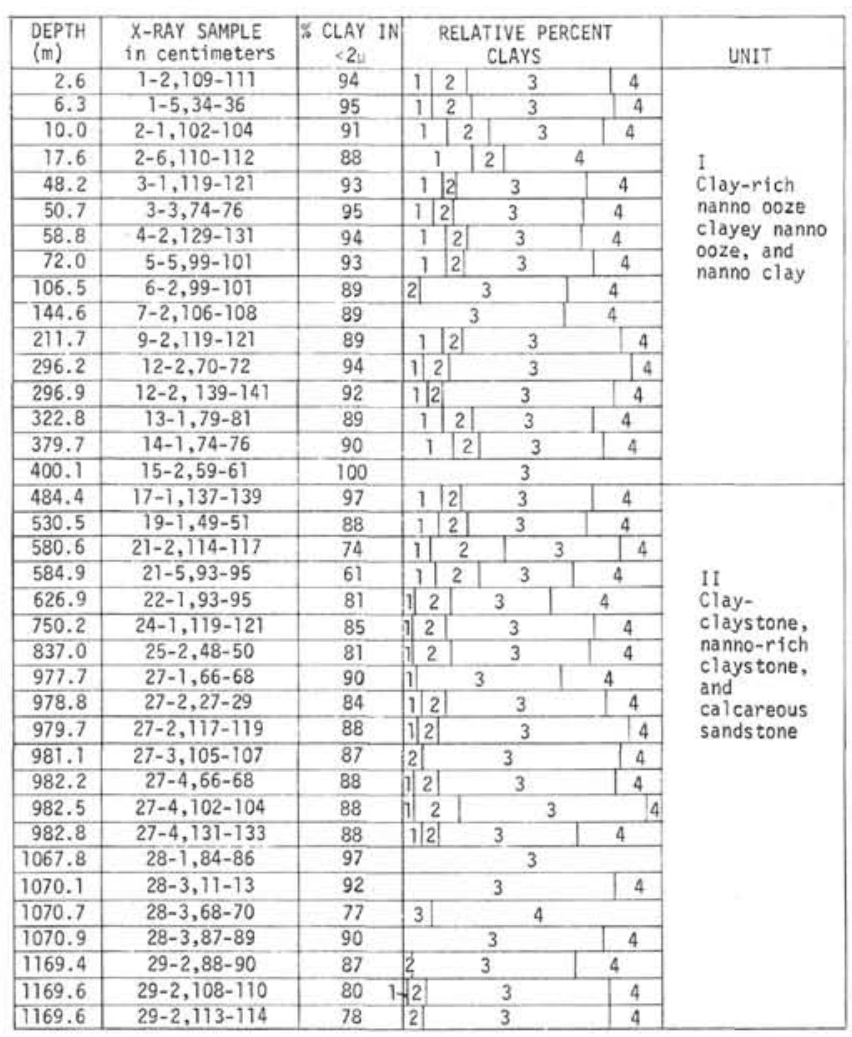

1 Kaolinite 2 Mica

3 Montmorillonite

4 Palygorskite

Figure 4. Relative percent clays, Site 241. For stratigraphic column, see Chapter 4, Figure 9. For $\mathrm{CaCO}_{3}$ diagram, see Chapter 4, Figure 8. evidence of relative clay percentages in the $<2 \mu$ X-ray fractions (Figure 5), which show that montmorillonite is an important contributor.

\section{Site 245}

Site 245 (Holes 245 and 245A) is located in the southern part of Madagascar Basin about 200 miles northwest of the Southwest Indian Ridge axis. Nineteen cores were recovered from Hole 245 and seven from Hole 245A. The combined stratigraphic column is a sequence of nanno chalk, nanno ooze, and brown clay (bottom to top) that records a deepening pelagic realm, most likely related to the subsidence of the sea floor as it moved away from the Central Indian Ridge.

Four major sediment units overlie basalt "basement". Unit I is a brown clay about 63 meters thick. Unit II consists of interbedded brown clay and nanno ooze and is also about 63 meters thick. Unit III is a clay-rich nanno ooze, 83 meters thick, and Unit IV is a clay-rich nanno chalk, 118 meters thick. Relative volcanic contributions to the sediments, ages, $\mathrm{CaCO}_{3}$ content, and clay percentages are given in Figure 6.

The age of Unit I is reported as late Eocene and middle Miocene. However, age assignments are somewhat tenuous because of mixing due to core deformation and a general paucity of fossils. Sediments in Unit I probably record continuous deposition from late Eocene to Recent. Most sediments are brown clay and silt-rich brown clay. The silt fraction comprises quartz, feldspar, heavy minerals (hematite and biotite), and rare clinoptilolite. The clay fraction contains all four major clay mineral groups, and the abundance of kaolinite and illite-mica indicates a notable nonvolcanic terrigenous influence. this unit was deposited below the calcium carbonate compensation depth (CCD); no calcareous biogenic sediments remain. The volcanic contributions are reflected mostly in the montmorillonite (and palygorskite) contents of the clay fractions and apparentlv were quite small.

Unit II, the interbedded brown clay and nanno ooze sequence, is of middle and late Eocene age. Some rare silty clay beds contain detrital heavy minerals, which indicate a nonvolcanic terrigenous source, probably Madagascar. With increasing depth, detrital nonvolcanic clay contents decrease and the amount of palygorskite increases. If the palygorskite is a diagenetic mineral formed from the alteration of ash, then this evidence suggests that volcanism was more prevalent in this unit than in the succeeding one (Unit I).

Unit III is mostly early Eocene in age and consists predominantly of clay-rich nanno ooze. In the noncarbonate portion, besides the ubiquitous clay minerals, manganese micronodules and clinoptilolite are commonly present. A few fragments of brown chert and semilithified chalk layers occur near the base of Core 4, Hole 245. One X-ray sample $(<2 \mu)$ from Unit III contains palygorskite, montmorillonite, and illite-mica. Although no discrete ash layers or other stratigraphic evidence for volcanism were noted, most of the clay fraction probably was derived from the alteration of volcanogenic materials.

Unit IV is a clay-rich nanno chalk of early Paleocene to early Eocene age. Sediment consists of semilithified nanno 


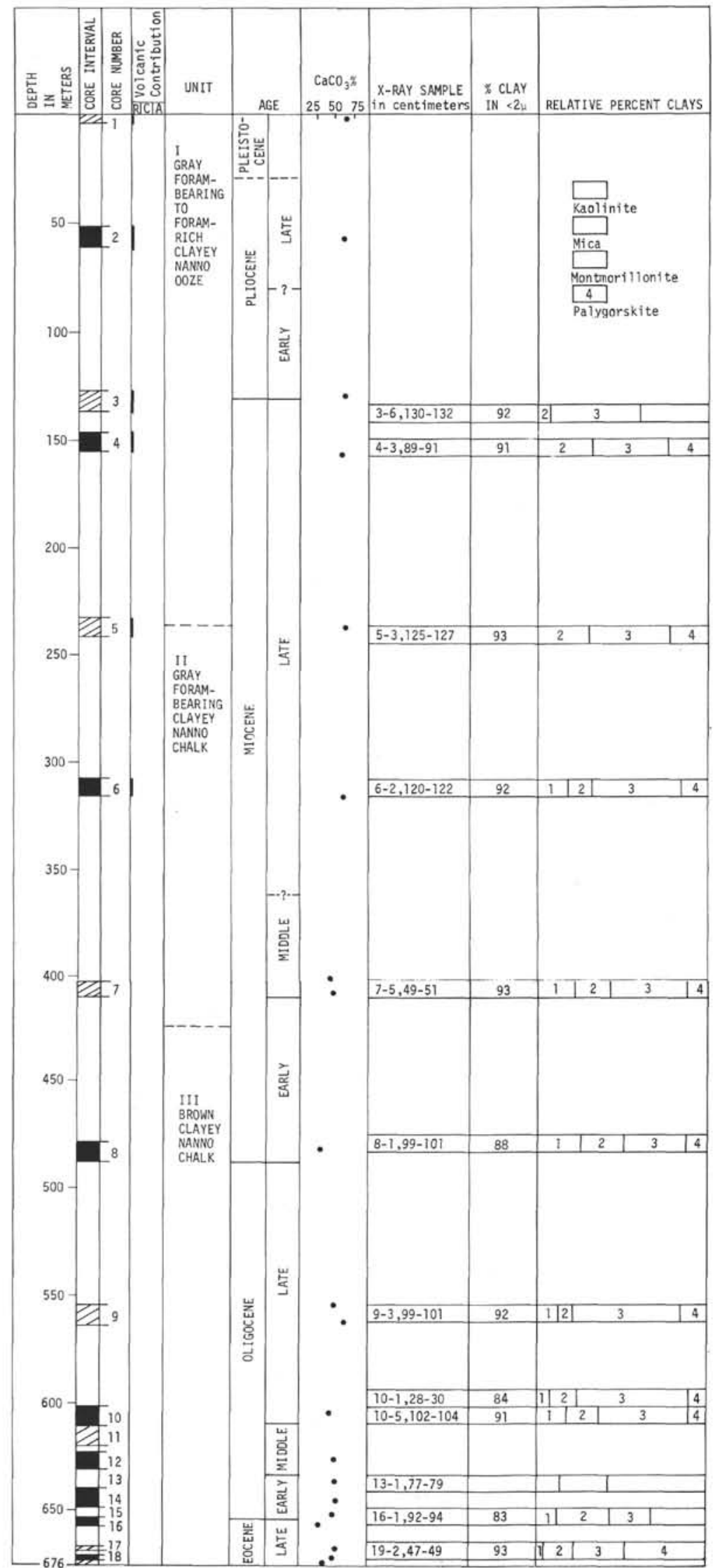

Figure 5. Volcanogenic sediments, Site 242, with $\mathrm{CaCO}_{3}$ and clay percentages. Dashed lines in "age" column signify uncertain boundaries. In "volcanic contributions" column, $\mathrm{R}=$ rare, $\mathrm{C}=$ common, and $\mathrm{A}=$ abundant . 


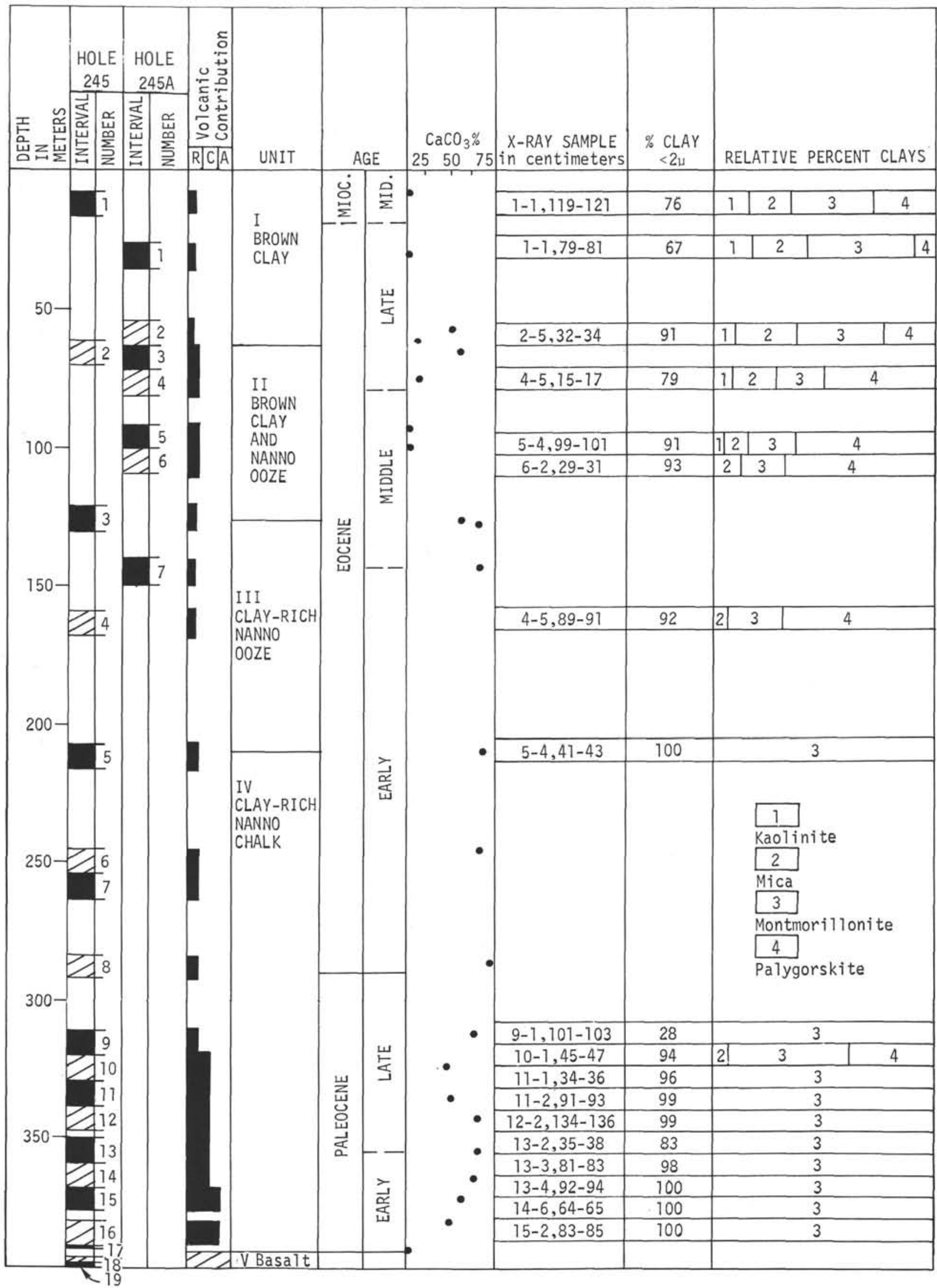

Figure 6. Volcanogenic sediments, Holes 245 and $245 \mathrm{~A}$, with $\mathrm{CaCO}_{3}$ and clay percentages. Dashed lines in "age" column signify uncertain boundaries. In "volcanic contributions" column, $\mathrm{R}=$ rare, $\mathrm{C}=$ common, and $\mathrm{A}=$ abundant. 
ooze and nanno chalk with minor amounts of chert, silicified chalk, and devitrified volcanic ash. Three subunits are recognized in Unit IV. Subunit IVA is a clay-rich nanno chalk with some silicified interbeds. The sediment is greatly bioturbated. Although only one discrete ash layer is present (Core 5), the greatly bioturbated zones in the chalk may have been ash-rich, thereby indicating a greater volcanic influence. In subunit IVB, also a clay-rich nanno chalk sequence, 22 devitrified ash beds occur, ranging in thickness from 0.5 to $10 \mathrm{~cm}$ (Figures 7 and 8 ). Outlines of glass shards, now completely replaced by montmorillonite, and fresh plagioclase grains are the major components of the beds. In other parts of the unit, a significant increase in clay content (predominantly montmorillonite) occurs, which suggests that volcanic ash was a significant contributor to the sediment column. Burrow mottling is very common close to the ash layers (Figure 9), indicating higher feeciing in the nutrient-rich volcanic sediment.

Subunit IVC, the lower part of Unit IV (368-389 m), overlies basalt. In this nanno chalk sequence, two major characteristics are significant. First is the increased clay (montmorillonite) content and second is the occurrence of a high concentration of ferromanganoan oxides, which gives the subunit a brown to olive black color. Devitrified ash layers also are abundant (Figure 10). Increased montmorillonite content, along with the presence of ash beds, are considered to be strong evidence for volcanic activity. The $\mathrm{Fe} / \mathrm{Mn}$ enrichment might be only indirectly related to volcanism (e.g., hydrothermal activity).

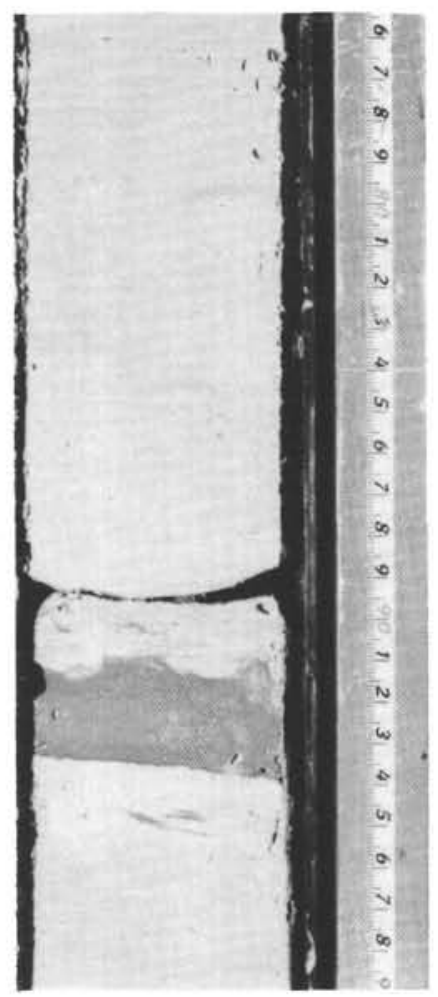

Figure 7. 245-11-2, 75-100 cm. Thin devitrified volcanic ash bed in nanno chalk, Unit IV Hole 245. Note the sharp lower contact and the irregular upper contact.

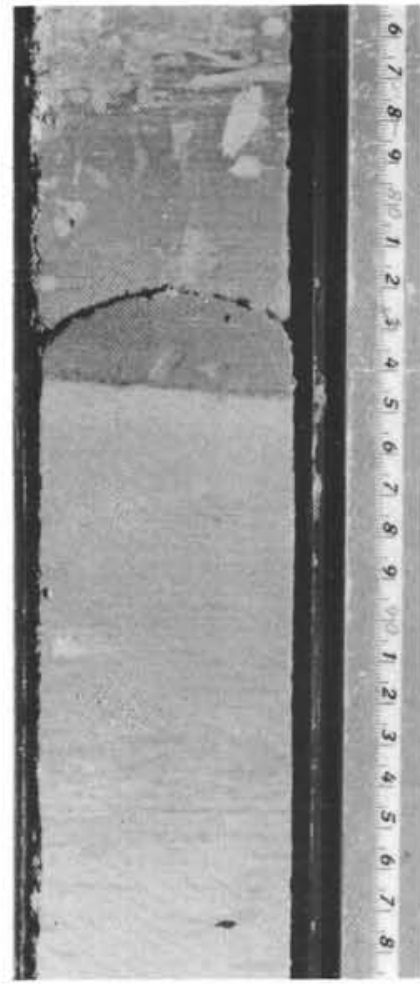

Figure 8. 245-13-3, 75-100 cm. Devitrified volcanic ash bed in nanno chalk showing a sharp lower contact and a heavily-burrowed and gradational upper contact.

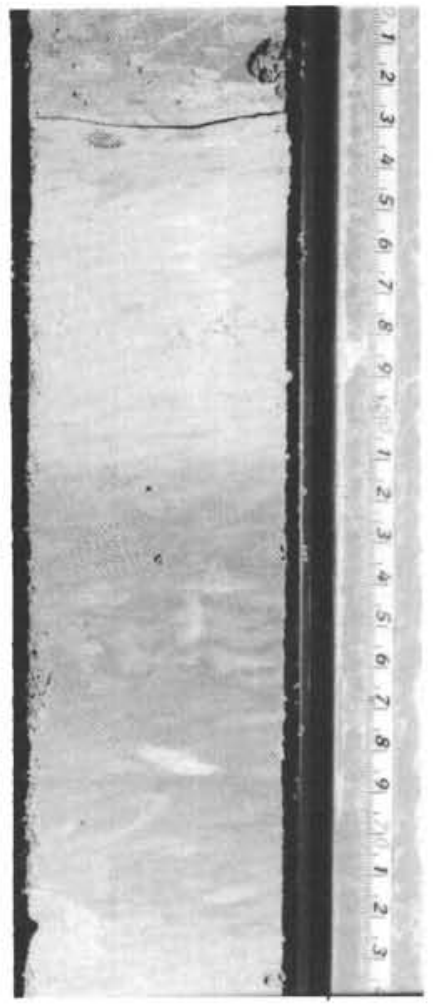

Figure 9. 245-14-4, 50-74 cm. Heavily-burrowed, montmorillonite-rich nanno chalk believed to represent an ash-rich interval. 


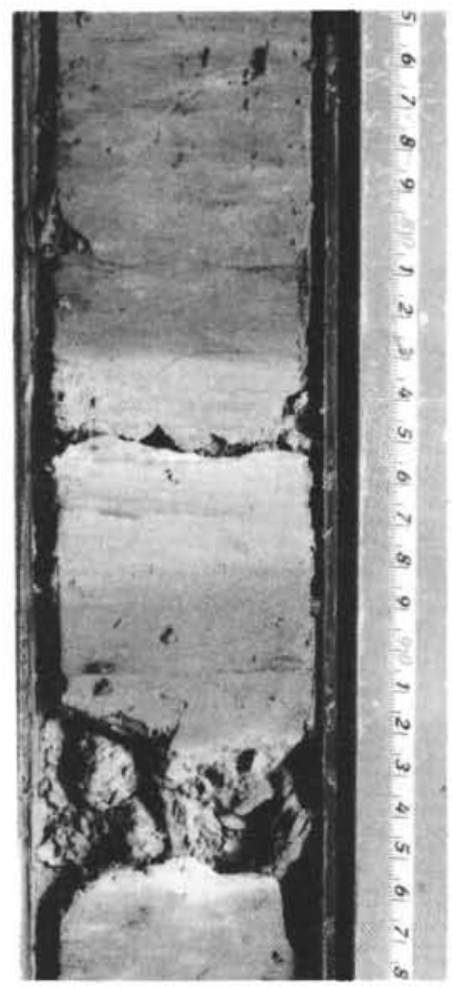

Figure 10. 245-15-2, $75-99 \mathrm{~cm}$. Leached devitrified volcanic ash layer $(83-88 \mathrm{~cm})$ in dark brownish gray ferromanganoan nanno chalk, Unit IV, Hole 245.

Warner and Gieskes (this volume) found high $\mathrm{Fe} / \mathrm{Mn}$ contents in the carbonate-free fractions of samples from subunit IVC. They also analyzed volcanic ash layers and found some diagnostic chemical characteristics, both in major elements and in trace elements.

\section{Site 246}

Site 246 was drilled on the Madagascar Ridge in 1030 meters of water. Objectives of drilling at the site were not reached because of difficulties associated with hole stability in coarse sand. Although 11 cores were cut between the sea floor and 203 meters, only 23.8 meters were recovered. Three major lithologic units were distinguished.

A summary diagram (Figure 11) is given to show the relative amounts of volcanic contributions in Hole 246 plus the ages, $\mathrm{CaCO}_{3}$ contents, and clay percentages. The upper unit, Unit I (Cores 1-4), is mostly coarse foram sand which ranges in age from early Miocene to Quaternary. No known volcanic products occur in this unit. Unit II (Cores 4-9) is a shelly carbonate sand. The top of the unit at 125 meters is marked by a $10-\mathrm{cm}$-thick bed of volcanic breccia which comprises the youngest (early Miocene) volcanic rock in the hole. This breccia is definitely epiclastic and consists of basalt rock fragments, rounded quartz grains, and forams, all cemented by sparry calcite. Montmorillonite is the only clay present in samples from Cores 8 and 9, thereby indicating a strong volcanic influence in the finer grained fractions.

Unit III (Cores 10 and 11) is the oldest unit cored (early Eocene) and consists of glauconite-bearing to glauconite- rich carbonate sand and shell/zeolite-rich volcanic sand, volcanic sandstone, and vitric tuff. Volcanic sand and tuff are at the following intervals: 10-2, 70-150 cm (Figure 12), $11-1,79-96 \mathrm{~cm}$, and $11-2,77-87 \mathrm{~cm}$. Maximum grain diameters are in the coarse-silt to coarse-sand range, although some rare clasts have diameters of nearly $1 \mathrm{~cm}$. Rare beds show grading and cross bedding. Some clay intervals between the sandstones and lithified tuffs are devitrified vitric tuffs.

Seven thin sections were prepared from five intervals in Unit III (Samples 10-2, 137-138 cm; 10-2, 140-145 cm; $11-1,128-132 \mathrm{~cm} ; 11-2,80-82 \mathrm{~cm}$; and $11-2,82-84 \mathrm{~cm}$ ). All are lithic tuffs which have poorly sorted glassy basalt fragments (1-12 $\mathrm{mm}$ in diameter), feldspar crystals, and opaque minerals enclosed in a cement + matrix of sparry calcite, phillipsite, analcite, goethite, and montmorillonite (Figures 13-15). The glassy basalt fragments have open reticulate frameworks. Feldspar phenocrysts are partly replaced by calcite, phillipsite, and analcite. Feldspar microlites in some basalt fragments are replaced by analcite and clinoptilolite(?). Rare crystals of mafic minerals are replaced by a fibrous amphibole (actinolite-tremolite according to X-ray diffraction studies). Phillipsite and analcite act as cementing agents, fill vesicles, and replace feldspars. Many filled vesicles in the glassy basalt fragments form spherulitic structures which have cristobalite and feldspar(?) intergrown in axiolitic structures. Rare foram tests and glauconite fragments are included in two thin sections.

Madagascar Ridge has been a submarine high since at least early Eocene. Walters Shoals, at a depth of about 20 meters is presently the high point on the ridge. Apparently, parts of the ridge have undergone shallow-water erosion during the early Eocene-Recent time interval and, undoubtedly, there were times when parts were above sea level. The sediments at Site 246 record high energy environments; some probably were deposited near wave base.

In summary, the volcanic sediments have the following characteristics:

1) Most are lithic tuffs, composed of glassy basalt fragments, feldspar, and opaques in a cement + matrix of calcite, zeolites, and montmorillonite.

2) The glassy rock fragments have an open reticulate structure that shows very little compaction effects and no welding characteristics.

3) Diagenesis occurred when the overburden was thin. Most diagenetic changes are the result of authigenesis-the creation of new minerals-which not only replaced preexisting minerals but also crystallized in the pore spaces. Major authigenic minerals include feldspar(?), cristobalite, phillipsite, analcite, and clinoptilolite. Calcite also recrystallized to form a large proportion of the cementing material. Montmorillonite is abundant and was formed by the devitrification of volcanic glass.

4) Included glauconite suggests that the volcanic components were transported through relatively shallow water. However, no known nonvolcanic terrigenous detritus occurs in the samples.

Because of the absence of terrigenous nonvolcanic detritus and the notable lack of welding effects, it is 


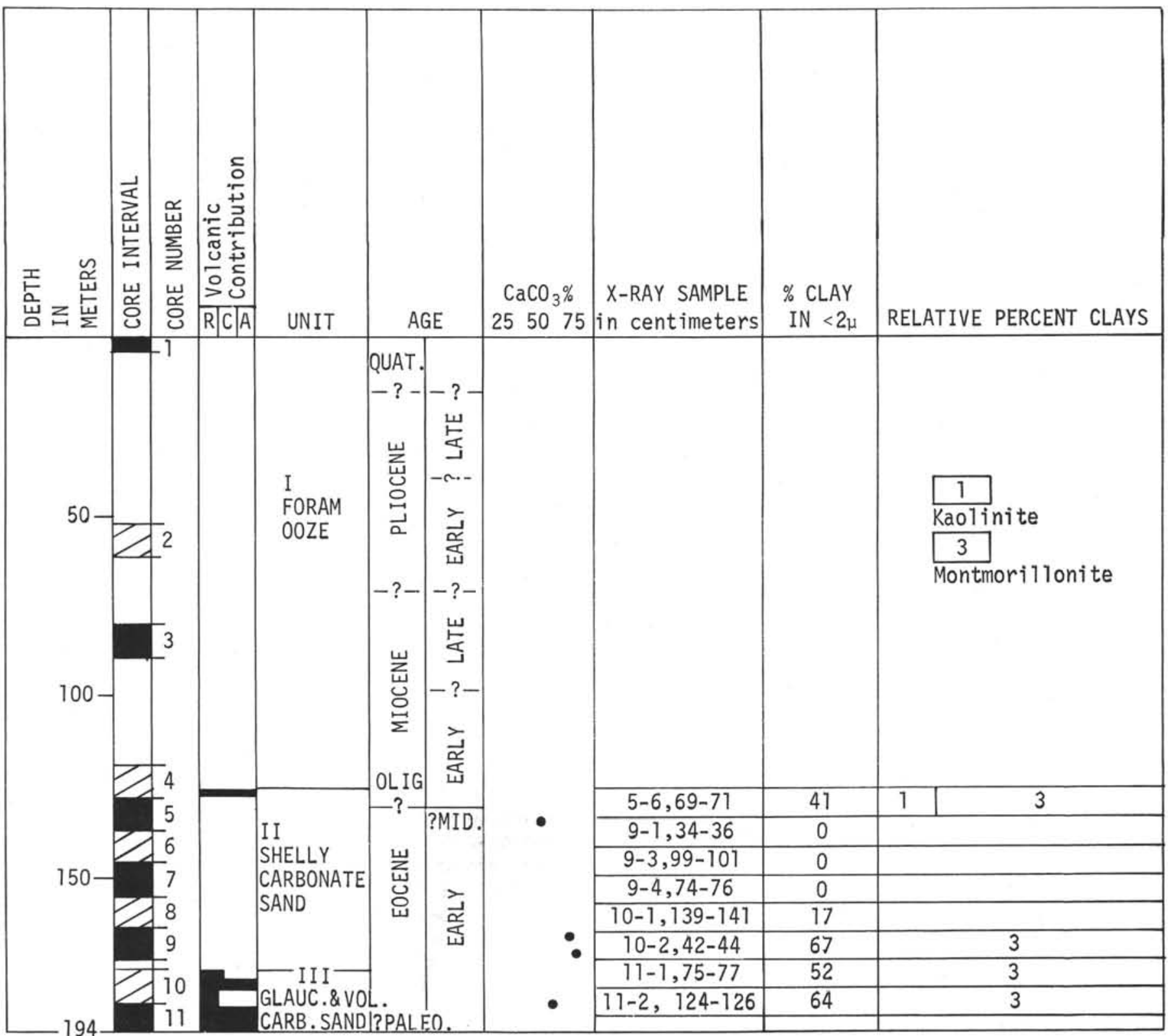

Figure 11. Volcanogenic sediments, Site 246, with $\mathrm{CaCO}_{3}$ and clay percentages. Dashed lines in "age" column signify uncertain boundaries. In "volcanic contributions" column, $\mathrm{R}=$ rare, $\mathrm{C}=$ common, and $\mathrm{A}=$ abundant .

believed that either the volcaniclastic rocks are of subaqueous origin or they were erupted from a subaerial vent and transported directly to the sea floor. Rare included glauconite indicates that the sediments were transported over the sea floor before deposition. However, the general homogeneity of the samples suggests that there was very little mixing during transport. Although evidence is not conclusive, it seems most likely that eruptions occurred in shallow water and the volcanic sediments were transported as pyroclastic flows across the sea floor.

\section{Site 248}

Site 248, located in the Mozambique Basin, was drilled to a depth of 434 meters below the sea floor; 17 cores were cut and 40.8 meters of sediment was recovered. The sediment column is divided into three units overlying basalt
(Figure 16): Unit I is a terrigenous unit of silt, clay, and sand; Unit II is a volcanic clay and volcanic silty clay; and Unit III is a brown clay.

Unit I (Cores 1-9) consists of silt, clay, and coarse sand. Ages range from middle Miocene to Pleistocene. Smear slide, heavy mineral, and X-ray data indicate a dominantly terrigenous origin for this unit; no volcanogenic sediments were noted.

Unit II (Cores 10-13) is a greenish-gray sequence that originally was volcanic clay and volcanic silty clay. It contrasts greatly with other units, not only at this site, but also at other sites drilled during Leg 25. Notable characteristics include bedding, color, and mineralogy. Beds are generally thin $(0.5-10 \mathrm{~cm})$; some more appropriately are called laminae. Slight differences in color (grayish green and light brown) generally define the bedding. Rare white and 


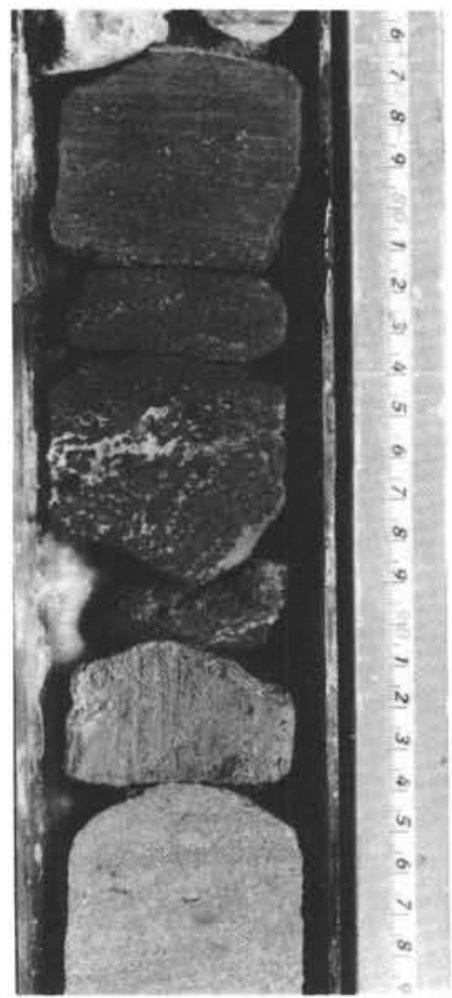

Figure 12. 246-10-2, 76-99 cm. Glassy. basalt tuff and basaltic tuff breccia.

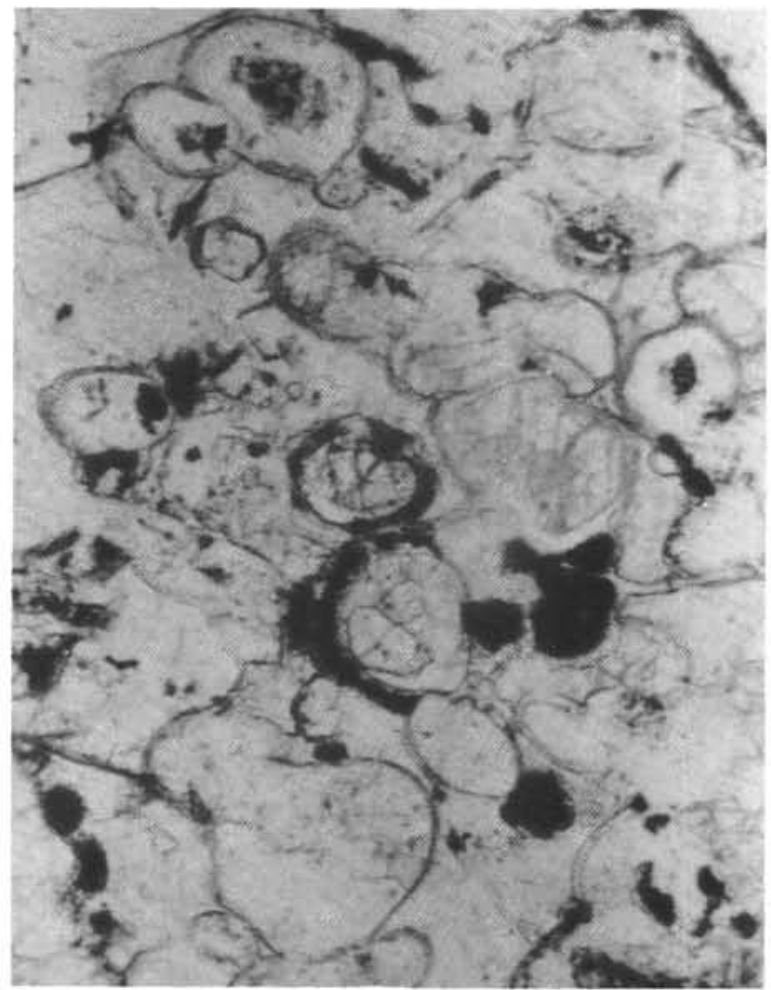

Figure 13. 246-10-1, 137-138 cm. Photomicrograph of glassy basalt fragment. Note the open reticulate structure with openings now filled with analcite and phillipsite. Field of view is about $0.6 \mathrm{~mm}$ in length.

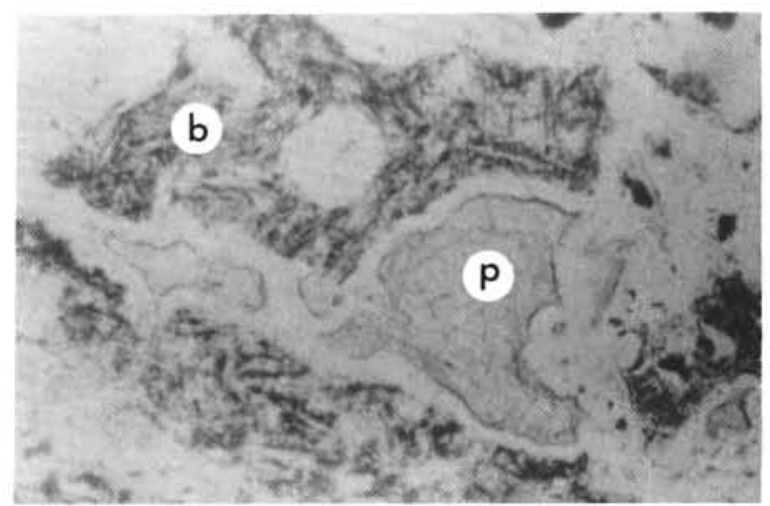

Figure 14. 246-10-1, 137-138 cm. Photomicrograph of slight yellow phillipsite $(\mathrm{P})$ showing a radiating structure with glassy vesicular basalt fragment (b). Field of view about $0.6 \mathrm{~mm}$ in length.

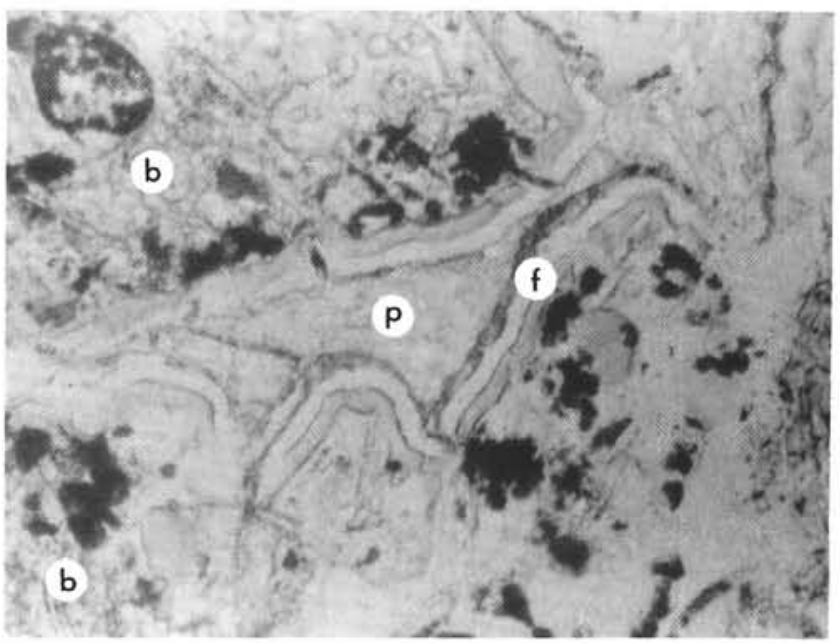

Figure 15. 246-10-1, 137-138 cm. Photomicrograph of glassy basalt fragments (b) cemented by phillipsite (P) with an authigenic silicate rim consisting of feldspar (f) and perhaps cristobalite (?). Field is about $0.6 \mathrm{~mm}$ in length.

light-pink laminae consist of silt-sized carbonate (rhodochrosite) and brownish-gray, clay-rich beds mark devitrified volcanic ashes (Figure 17). Pyrite occurs as thin laminae (concentrations along bedding planes) and as distinct segregations. In the lower part, heavy minerals include opaques, chlorite, and rare hornblende, but toward the top, a distinctive heavy mineral suite indicates an increasing terrigenous influence. The presence of cristobalite, tridymite, and clinoptilolite and the dominance of palygorskite over montmorillonite in the clay fractions are significant mineralogic characteristics. Potash and plagioclase feldspars are important contributors.

Studies of six thin sections from three intervals (10-2, $135-138 \mathrm{~cm} ; 11-3,112-115 \mathrm{~cm}$; and $13-1,120-124 \mathrm{~cm}$ ) were not of much assistance in mineral studies because the sediments are very fine grained. X-ray samples were taken 


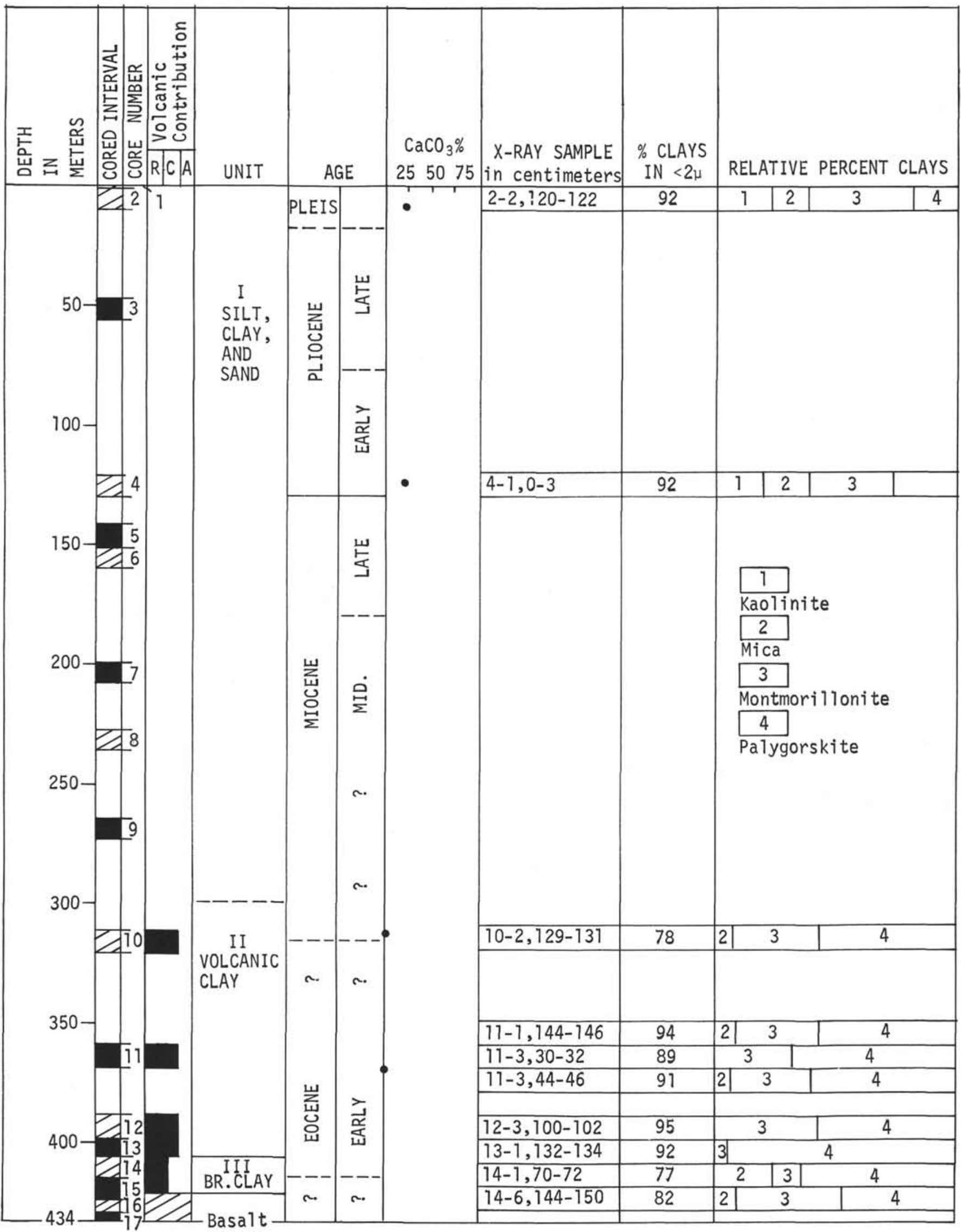

Figure 16. Volcanogenic sediments, Site 248, with $\mathrm{CaCO}_{3}$ and clay percentages. Dashed lines in "age" column signify uncertain boundaries. In "volcanic contributions" column, $\mathrm{R}=$ rare, $\mathrm{C}=$ common, and $\mathrm{A}=$ abundant. 


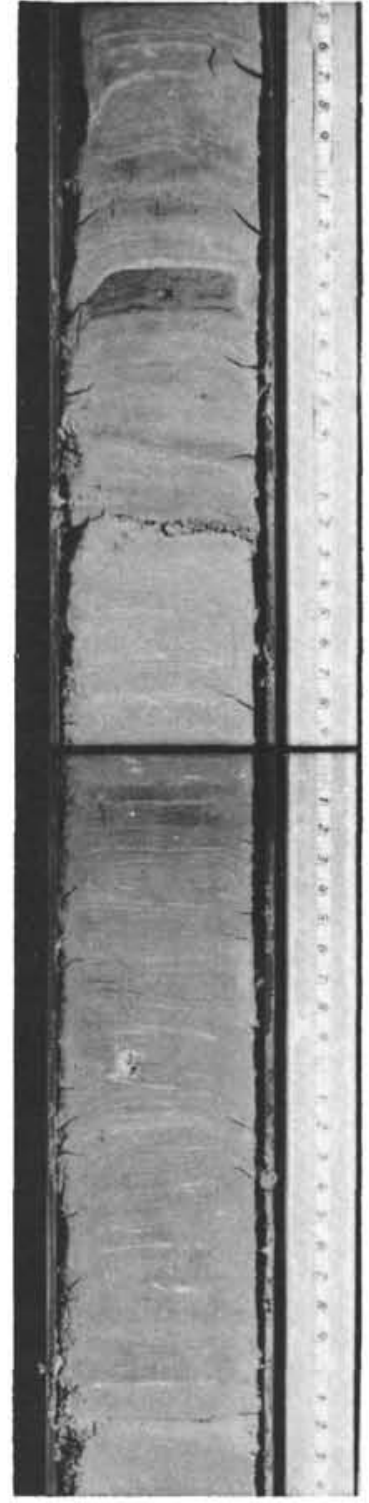

Figure 17. 248-12-3, 25-74 cm. Thinly bedded and laminated volcanic silty claystone. Darker bed at 34-35 $\mathrm{cm}$ is a devitrified volcanic ash. Some thin white laminae contain rhodochrosite.

near the thin section samples to assist in mineral identifications. One bulk X-ray sample at $10-2,129-131 \mathrm{~cm}$ is characteristic of the sediment (quartz, 18\%; cristobalite, $22.8 \%$; tridymite, $3.3 \%$; potash feldspar, $2.2 \%$; plagioclase, $6.5 \%$; illite-mica, $7.1 \%$; palygorskite, $28.3 \%$, and montmorillonite, $12.0 \%$ ). A probably devitrified volcanic ash layer at 13-1, 132-134 cm has an X-ray bulk mineralogy of quartz, 6.8 percent; illite-mica, 4.3 percent; montmorillonite, 7.0 percent, and palygorskite, 81.9 percent. The silica minerals quartz, cristobalite, and tridymite occur mostly as thin veins, irregular segregations, and as small, widely dispersed grains in a "felty" matrix of palygorskite and montmorillonite. Radiolarian tests are opaline; only rarely are they replaced by the well-crystallized silica minerals. Radiolarian tests are current deposited and are concentrated in lens-like layers and in thin beds, generally associated with silt grains of quartz, feldspar, and chlorite. Rare, thin beds of silt (mostly quartz and feldspar grains) occur throughout the unit.

Reducing conditions are suggested by the color (grayish green), and by the occurrences of both rhodochrosite and pyrite (Lynn and Bonatti, 1965). Clinoptilolite, associated with the magnesium silicate palygorskite (Core 12;393 m), is probably the result of a reaction of magnesium-rich solutions with either volcanic glass or minerals of the smectite family (Bonatti, 1972).

The abundance of montmorillonite and palygorskite in the sediment, plus the presence of devitrified volcanic ash beds, indicate that volcanic sediments are abundant in Unit II. The association of silica minerals (quartz, cristobalite, and tridymite) with volcanic detritus in this sequence leads to some speculations as to the origin of siliceous rocks. Except in chert, the occurrence of authigenic quartz in deep-sea sediments has not been well documented. However, both cristobalite and tridymite have been reported in deep-sea sediments from a large variety of settings. Excess $\mathrm{SiO}_{2}$ can be derived from one or more of several sources including hydrothermal emanations, diagenesis of opaline radiolarian tests, devitrification of volcanic glass, and diagenesis of clay minerals. Except for the presence of rhodochrosite, which might suggest a hydrothermal association, no direct evidence for hydrothermal activity exists in the sediment of Unit II, and that source can be largely discounted. Radiolarian tests may have provided some of the silica. A few spherule-like concentrations of cristobalite and tridymite occur, and there is a distinct possibility that these represent replaced tests. However, most tests still are opaline and the diagenesis of radiolarian tests certainly is not the only source of excess $\mathrm{SiO}_{2}$. The most likely source is the devitrification of volcanic glass and/or the silica released by the smectite clays during diagenesis. McKenzie and Garrels (1965) point out that silica saturation depends not only on the temperature and $p \mathrm{H}$ conditions of the water, but also on the clay minerals. These aluminosilicates release silica to seawater that is low in $\mathrm{SiO}_{2}$ concentration. During diagenesis, excess $\mathrm{SiO}_{2}$ can be reconstituted authigenically into cristobalite and tridymite. This loss of $\mathrm{SiO}_{2}$ by the smectites might also contribute to the formation of palygorskite. Yet another possibility is that palygorskite and $\mathrm{SiO}_{2}$ minerals form together because the original sediment was indeed silica-rich (Lancelot, 1973).

The sediments of Unit II are strongly volcanogenic and have undergone diagenesis in the presence of excess $\mathrm{SiO}_{2}$. The original sediment was both pyroclastic (distinct ash beds) and epiclastic in origin. The source of the volcanic detritus is not known but the early Eocene age, which is the same as that at Site 246 on Madagascar Ridge, suggests that volcanism was quite extensive at that time. The sediment was deposited below the CCD, and the grayish-green color and abundant pyrite suggest a reducing environment. The association with Radiolaria indicates a probable increase of silica in the surface waters, perhaps as a result of the volcanic activity.

Unit III (Core 14) is a brown clay which is enriched in iron and manganese (Marchig and Vallier, this volume). 
Deposited mostly in an oxidizing environment, this unit stands in strong contrast to the overlying sediment of Unit II. The presence of illite, kaolinite, and chlorite, plus the high quartz and potash feldspar percentages, indicate a notable nonvolcanic terrigenous influence. Green and brown colors alternate near the top of Core 14 suggesting that depositional conditions between Units III and II changed gradually from oxidizing to reducing. Montmorillonite and palygorskite abundances are not greatly different from those in Unit II, inferring that fine-grained volcanogenic sediments subsequently yielded most of the clays.

\section{Site 249}

Site 249, located on the Mozambique Ridge, was the most completely cored hole on Leg 25 . Thirty-three cores were cut over a 412-meter interval. Three major units are recognized above the basalt (Figure 18). Unit I, the top 172 meters (Core 1-16), is a foram-rich nanno ooze that ranges from Miocene to Pleistocene in age. Unit II (Cores 16-23) is a foram-bearing clay-rich nanno chalk, entirely of Late Cretaceous age (Campanian-Maestrichtian) that occurs at a depth of between 172- and 287-meters below the sea floor. Unit III (Cores 23-32), between a subbottom depth of 287 meters and basalt at 408 meters, consists mostly of gray and olive-black silty claystone, volcanic siltstone, silty limestone, and tuff.

The boundary between Units I and II coincides with a Late Cretaceous (Maestrichtian)-middle Miocene unconformity. Unit I contains no direct evidence for volcanism, and because clay content is very small, no X-ray samples were taken. In Unit II, the $2-20 \mu$ carbonate-free X-ray results show a large percentage of quartz and feldspar with clay fractions of montmorillonite, palygorskite, mica (mostly illite, but some might be detrital muscovite), and chlorite. Palygorskite and montmorillonite are the only clay minerals in the $<2 \mu$ fraction in two samples from Core 21 $(258 \mathrm{~m})$. No direct evidence for volcanic contributions occurs in Unit II. The clay content is indirect evidence for volcanism, but the clays most probably were eroded from eastern Africa and transported by surface currents and winds to Site 249.

Unit III (Neocomian to either late Aptian or early Cenomanian in age) has abundant evidence of volcanic material. The presence, not only of volcanic sediments, but also of abundant pyrite and an organic carbon content greater than one percent is in contrast to the overlying chalk. The sediments rest on a deeply weathered, highly vesicular basalt (Figure 19). Unit III is divided into subunit IIIA (Cores 23-28), which consists of silty claystone, silty limestone, tuff, tuffaceous siltstone, and calcareous siltstone, and subunit IIIB (Cores 29-32), which consists predominantly of calcareous silty claystone and clayey siltstone.

In subunit IIIA, there are tuff beds, tuffaceous siltstone layers, abundant glassy basalt fragments, and glass in some siltstone beds, which indicate a strong volcanic influence. X-ray analyses show calcite, quartz, cristobalite, tridymite, plagioclase, clinoptilolite, pyrite, and montmorillonite as major contributors in the siltstone and claystone with potash feldspar and mica as minor contributors. Tuff beds (some may be epiclastic siltstone and sandstone) occur in the top part of subunit IIIA in Cores 23-26 (Figures 20 and 21) along with volcanic siltstone. Volcanic materials decrease in abundance with depth.

Besides smear slide and X-ray studies, nine thin sections were described (Table 1). Rock types studied in subunit IIIA are silty limestone, clayey siltstone, basaltic tuff, and tuff (volcanic siltstone?) (Figures 22-24). In subunit IIIB, only calcareous silty claystone and clayey siltstone were studied.

Cores 24 and 25 (subunit IIIA) contain the most abundant volcanic material. Distinct beds of glassy basalt tuff with crude graded bedding are common. One sample $(25-3,126-218 \mathrm{~cm})$ has glauconite incorporated, indicating a possible epiclastic origin. However, the glauconite may have been incorporated within a subaqueous pyroclastic flow that moved across the ocean floor. The volcanism was definitely basaltic and was erupted either subaerially or in very shallow water. The amount of volcanogenic sediment decreases with depth in subunit IIIA; however, indirect evidence (smectite family as the only clay, abundant authigenic $\mathrm{SiO}_{2}$ minerals, and clinoptilolite) remains strong. Subunit IIIA suggests increasing volcanic activity with time, culminating in the deposition of basaltic tuffaceous rocks. Volcanic contributions in the lower part probably represent products from an eroding volcanic landmass along with some wind blown volcanic ash.

Subunit IIIB is mostly calcareous clayey siltstone, clayey siltstone, and silty claystone. The abundance of montmorillonite as the dominant clay and the presence of some volcanic rock fragments and glass shards in the coarser siltstone beds indicate a fairly strong volcanic influence. Glauconite grains (fecal pellets and test fillings) are abundant in some samples. Clinoptilolite, cristobalite, and tridymite are common and sparry calcite cement probably represents recrystallized calcareous nannoplankton or foraminifera tests. The organic carbon, pyrite, and lack of any burrows strongly suggest that both subunits were deposited in a restricted (euxinic) basin.

\section{CORRELATION OF REGIONAL VOLCANIC ACTIVITY}

Volcanic activity, as determined by the volcanogenic sediments in sites drilled in the western Indian Ocean, was relatively uncommon during the Cretaceous to Recent time interval. Notable exceptions are the Early Cretaceous of the Mozambique Ridge (Site 249), the Late Cretaceous of the western Somali Basin (Site 241), the Paleocene of Madagascar Basin (Site 245), the Eocene of both the Madagascar Ridge (Site 246) and the Mozambique Basin (Site 248), and somewhat irregularly throughout the Tertiary in the Mascarene Basin (Site 239).

The major purpose of this section is to relate sea floor volcanism, as interpreted from sediments drilled on Leg 25 , to continental, island, and mid-oceanic ridge volcanism.

Figure 25 correlates the major volcanic events on India, Madagascar, East Africa, the Comoro and Mascarene islands, and the volcanism at sites drilled on Leg 25 , as indicated by their volcanogenic sediments and basaltic "basement". 


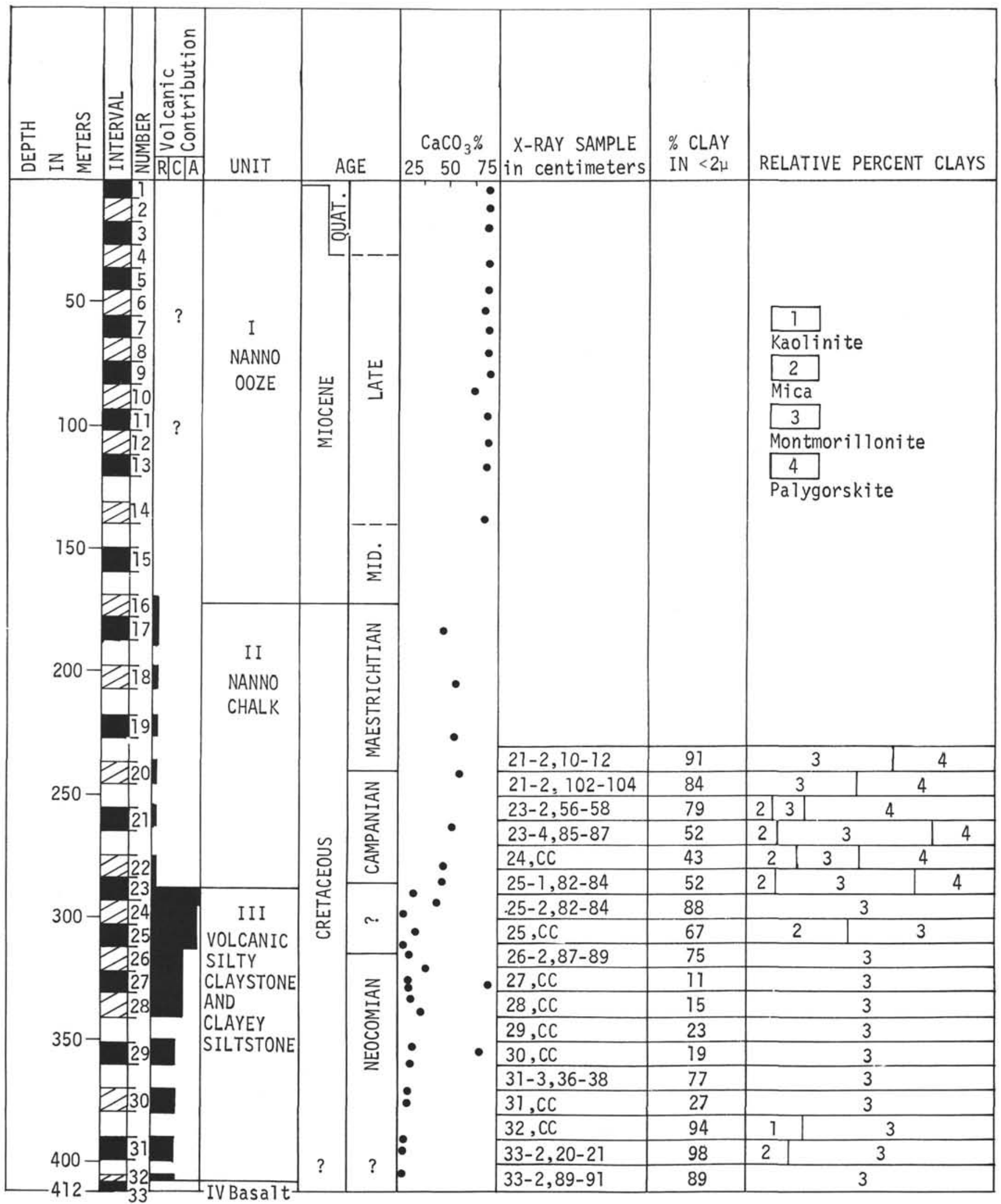

Figure 18. Volcanogenic sediments, Site 249, with $\mathrm{CaCO}_{3}$ and clay percentages. Dashed lines in "age" column signify uncertain boundaries. In "volcanic contributions" column, $\mathrm{R}=$ rare, $\mathrm{C}=$ common, and $\mathrm{A}=$ abundant . 


\section{Review of Related Continental and Island Volcanism}

This part contains a review of published and unpublished data concerning Cretaceous to Recent volcanism in southeastern Africa, Madagascar, India, and the Comoro and Mascarene islands. In conducting this review, consideration has been given to the inherent dangers of discussing the geology of areas which are unfamiliar to the writer. It will necessarily be brief and incomplete, but it is intended to familiarize the reader with major volcanic activity which, in the opinion of the author, is relatable to the western Indian Ocean volcanism.

\section{Southeastern Africa}

Extensive volcanism occurred in the Precambrian of southeastern Africa. According to Haughton (1963), most are basic lavas which have been metamorphosed to the greenschist facies. Tanner (1973, p. 2848), in a summary of Precambrian orogenic cycles of eastern Africa, states that the "greenstones" contain chlorite and biotite as secondary minerals. Weathering of these rocks does not produce montmorillonite, a valuable trace mineral in sediments for volcanism; therefore, the Precambrian volcanism is not considered in more detail here. Only the Karroo and younger volcanics are described.

A review of Karroo and younger volcanism in southeastern Africa is given by Flores (1970); in South Africa by Truter (1949), whose major conclusions are

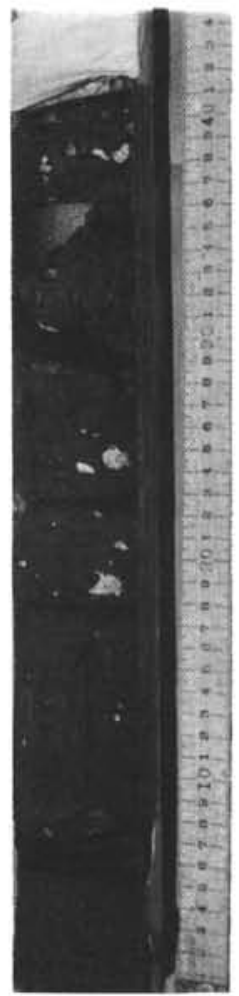

Figure 19. 249-33-1. Vesicular basalt flow. Note the larger vesicles near the top and the decreasing sizes with depth (left in photograph). Meter stick is used for scale only.

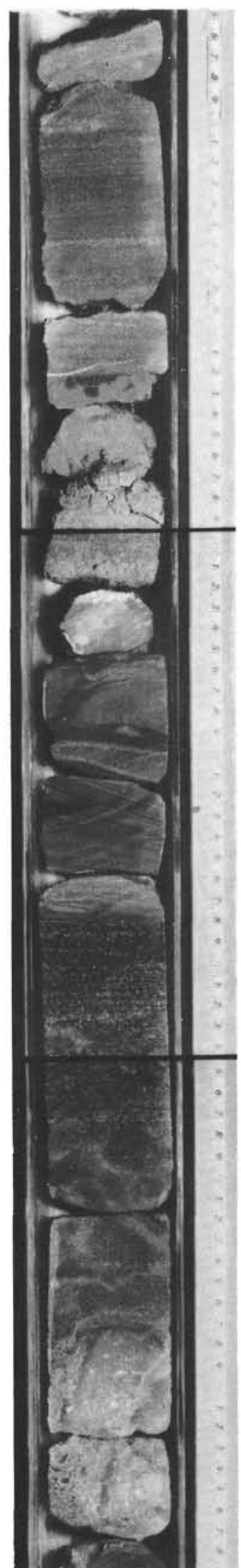

Figure 20. 249-23-5, 25-99 cm. Basalt tuff and tuff breccia. 


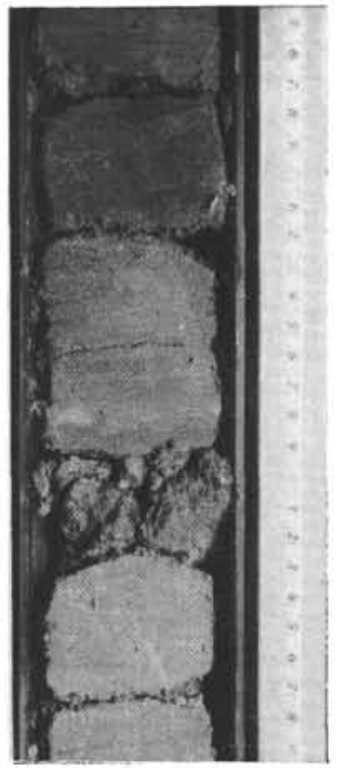

Figure 21. 249-25-2, 75-99 cm. Devitrified vitric (basaltic) tuff (volcanic sandstone?).

summarized in Table 2; and in southeastern Africa and Madagascar by Blant (1973). Flores (1970) relates volcanism in southeastern Africa and Madagascar to the widening split between Africa and Madagascar which occurred when major fractures reached subcrustal depths and caused extensive outpourings along linear fissures, first in late Karroo (Jurassic) times (e.g., Lebombo Range) and then in the Cretaceous and Tertiary (e.g., Madagascar and mid-channel volcanism). Figure 26, after Flores (1970), shows the distribution of known Karroo (Jurassic) and Lower Cretaceous volcanics as well as that of Jurassic marine strata.

The Karroo Stormberg (Lias) and the Lower Cretaceous effusives in Africa are grouped by Flores (1970) because the two sequences are geographically and structurally related. He simplified the age relationships of the effusives by placing them in two major groups: (1) porphyritic "alkaline lavas" of Early Cretaceous age, i.e., Lupata alkaline lavas $(106,110,115 \pm 10 \mathrm{~m} . \mathrm{y}$. age dates) and "Movene Basalts" (137 m.y.) of latest Jurassic-earliest Cretaceous age; and (2) limburgites, basalts, rhyolites, tuffs, etc., of Jurassic age (166 \pm 10 m.y. and older). Group 2 is the thick (several thousand feet) Jurassic sequence from Lesotho (formerly Basutoland), the Lebombo Range, the Buzi area, the lower Zambesi Valley, etc. Group 1 is the Lower Cretaceous sequence present at Lupata (and elsewhere). To this group, Flores (1970, p. 10) assigns the "Movene Basalts", an extrusive unit that is stratigraphically above the Lebombo Range flows. He also correlates lavas from wells near the eastern Africa coast with those exposed in outcrops farther west.

Frankel's (1960) estimate of thicknesses is even greater than those of Flores (1970). He reports that the sequence in the Lebombo Range is as much as 15,000 feet thick, and above this sequence, is a combined thickness of 10,000 feet of Impamputo basalt, rhyolite of the Little Lebombo, and "Movene Basalts".
Based upon the above information, it can be concluded that during the Jurassic-Early Cretaceous time interval, volcanism was extensive in southeastern Africa. However, in the Late Cretaceous-Recent interval, volcanic activity was mostly limited to only a few alkalic volcanic centers (Haughton, 1963, p. 292-295).

\section{Madagascar}

Besairie (1972; 1973, personal communication) describes the Cretaceous-Recent volcanism in Madagascar. His sketch geologic map (Figure 27) shows volcanic rocks and associated shallow intrusives of Late Cretaceous to Recent ages. The brief review given here is a summary of his detailed explanation (personal communication, 1973).

Major volcanism occurred in the Early Cretaceous (Valanginian-Aptian), Late Cretaceous (Turonian and Campanian), Paleocene (tuffs in the north), Eocene, Miocene, and Pliocene-Pleistocene. The oldest known Cretaceous volcanism, not shown in Figure 27, is of Early Cretaceous (Valanginian-Aptian) age. These older volcanic rocks extend along the southeastern and western parts of the island. In some places, they are covered by transgressive facies (Maestrichtian and Eocene in the extreme southwest) and in other places they disappear due to faulting and erosion.

Important times of volcanism in the Late Cretaceous were mostly in the Turonian and Campanian. Volcanic eruptions (mostly tholeiitic basalt) occurred in the late Turonian, at the Turonian-Coniacian boundary, and in the Campanian. Most Turonian lavas are in the northwest and west (Majunga Basin), although some equivalent flows are in the southwest (Morondava Basin). On the northeastern coast, Turonian-lower Coniacian volcanics rest on Precambrian basement. The Campanian is represented by extensive outpourings of volcanic rocks. For example, in the southern part of Morondava Basin, Campanian volcanic rocks stretch for a long distance north of Cap Sainte Marie. These are dated at $70 \pm 7$ m.y. by K-Ar methods. In the extreme south, the massif at Androy is made up of alternations of basalt and rhyolite, with a maximum thickness of 800 meters, which have also been dated at $70 \pm$ m.y. On the southeastern coast, a wide band of basalt and sakalavite (glassy andesite), with some rhyolite and dellenite (rhyodacite), crop out for a length of about $500 \mathrm{~km}$ and have thicknesses of 100 to 500 meters. They rest on the Precambrian and are covered in part by lower Maestrichtian sediments. The basalts have furnished a $73 \pm 7$ m.y. K-Ar date. Farther north, between Vatomandry and the Bay of Antongil, a dolerite like swarm has been dated at $68 \pm 7$ m.y. and $80 \pm 7$ m.y. by the K-Ar methods.

In the north, extending mostly southeast from Ampasindava, alkaline intrusives are dated at 48 m.y. (Eocene) by $\mathrm{Rb} / \mathrm{Sr}$ methods. Several "massifs" of Miocene and Pliocene-Pleistocene ages extend from the north, at Bobaomby, to the central part at Ankaratra (see Figure 27). Most large "massifs" are made up of several rock types. For example, the large "massif" at Ankaizina includes trachyte, phonolitic trachyte, basalt, basanite, ankerite, and ignimbrites. The "massif" at Ankaratra, near the center of the island, has an older trachytic series covered by late Tertiary lacustrine beds. This is followed by an old basic series of 
TABLE 1

Modal Analyses of Rocks from Unit III, Site 249

\begin{tabular}{|c|c|c|c|c|c|c|c|c|c|c|c|c|c|c|c|c|c|}
\hline \multirow[b]{2}{*}{ 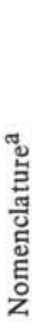 } & \multirow[b]{2}{*}{$\begin{array}{l}\text { 产 } \\
\text { 窇 }\end{array}$} & \multicolumn{16}{|c|}{ Component (volume percent) } \\
\hline & & 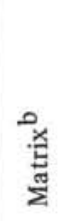 & $\begin{array}{l}0 \\
\frac{0}{0} \\
\frac{0}{\pi} \\
0\end{array}$ & 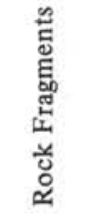 & 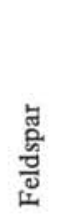 & 总 & 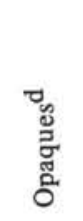 & 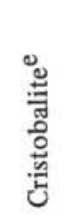 & 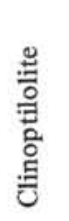 & 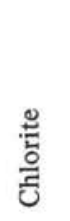 & 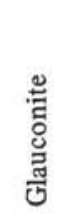 & 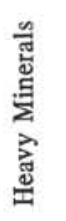 & 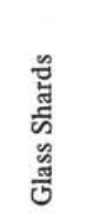 & 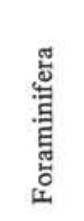 & 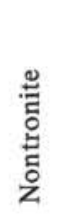 & $\begin{array}{l}\stackrel{\varpi}{\leftrightarrows} \\
\stackrel{\leftrightarrows}{0} \\
\approx \\
\approx\end{array}$ & ङू \\
\hline A & $23-4,127-129$ & - & 72.3 & 0.3 & 5.3 & 1.3 & 1.7 & 1.0 & 4.3 & 1.0 & - & - & - & 11.7 & 1.0 & - & 99.0 \\
\hline B & $24, \mathrm{CC}$ & 42.7 & 0.3 & 0.7 & 4.3 & 1.0 & 2.3 & 18.7 & 4.4 & 0.3 & 23.0 & 0.7 & 1.7 & - & - & - & 100.1 \\
\hline $\mathrm{C}$ & $25-2,82-89$ & - & - & $86.7^{\mathrm{f}}$ & 4.0 & - & 9.3 & - & - & - & - & - & - & - & - & - & 100.0 \\
\hline $\mathrm{D}$ & $25-3,15-17$ & - & $15.3^{\mathrm{g}}$ & - & 1.3 & - & 1.3 & - & - & - & - & - & $82.0^{\mathrm{h}}$ & - & - & - & 99.9 \\
\hline $\mathrm{E}$ & $25-3,90-82$ & 2.7 & 60.7 & $33.0^{\mathrm{i}}$ & 3.3 & - & - & - & - & - & - & - & - & - & - & - & 99.7 \\
\hline $\mathrm{F}$ & $25-3,126-128$ & - & Tr. & - & 3.3 & - & 3.0 & - & - & - & 1.0 & - & $92.7^{j}$ & - & - & - & 100.0 \\
\hline G & 25. CC & 1.7 & 68.7 & $\mathrm{Tr}$ & 4.3 & 0.3 & 5.0 & 3.0 & - & - & 16.0 & - & 1.0 & $\operatorname{Tr}$ & - & - & 100.0 \\
\hline $\mathrm{H}$ & $26, \mathrm{CC}$ & 50.7 & 17.0 & 1.0 & 2.7 & 0.7 & 5.7 & 8.0 & 7.0 & - & 7.0 & - & 0.3 & $\operatorname{Tr}$ & - & - & 100.1 \\
\hline I & $31-3,36-38$ & 40.3 & 7.0 & $\operatorname{Tr}$ & 7.6 & 1.3 & 13.0 & - & - & 7.0 & 9.0 & - & $\operatorname{Tr}$ & - & - & $14.7^{\mathrm{k}}$ & 99.9 \\
\hline
\end{tabular}

Note: 300 points counted for each slide
a Nomenclature
A. Silty limestone.
B. Glauconite-rich clayey siltstone.
C. Basaltic tuff.
D. Ash shard tuff (siltstone).
E. Tuffaceous limestone.
F. Ash shard siltstone.
G. Glauconite-rich silty limestone.
H. Calcareous silty claystone.
I. Clayey siltstone.

andesite and basalt, an intermediate series of ankaratrite (olivine nephelinite), and a young (Recent?) series of basanite and basalt that is covered by lignite dated at 6,000 to $8,000 \mathrm{C}^{14}$ years.

The island of Nosy Be, along the northwestern coast of Madagascar, has an older Pliocene phase of basalt and basanite. The latest phase (Recent) includes outpourings of basalt and ankaratrite.

\section{India}

No attempt is made here to review the volcanic history of India. However, the two recorded major basaltic trap rock series should be mentioned. The oldest, the Rajmahal Trap Basalts, have been dated at about 100-105 m.y. and the youngest, the Deccan Trap Basalts, are dated at about 59-65 m.y. (McElhinny, 1970). b Includes clays, fine-grained zeolites, organic carbon, and very small particles of cristobalite and tridymite in some thin sections.

${ }^{\mathrm{c}}$ Mostly sparry calcite cement.

dPyrite predominantly.

$\mathrm{e}_{\text {Includes tridymite. }}$

${ }^{\mathrm{f}}$ Glassy basalt fragments, replaced by nontronite.

geplaces glass shards.

$\mathrm{h}_{\text {Replaced by montmorillonite and calcite. }}$

${ }^{\mathrm{i}}$ Mostly scoriaceous glassy basalt.

$\mathrm{j}$ Now palagonite and montmorillonite.

$\mathrm{k}_{\text {Replaced mostly. }}$

\section{Comoro and Mascarene Islands}

Late Tertiary to Recent volcanism is recorded in the Comoro Islands. The archipelago apparently began forming in the early Miocene (Aquitanian), and Khartala Volcano still is active. In the southern part of the Mozambique Channel are the coral-capped islands of Bassas da India and Europa, which probably have volcanic pedestals; however, the ages of volcanism there are unknown.

The three islands which form the Mascarene Island group are Mauritius, Réunion, and Rodriguez. Volcanism on these islands (McDougall and Chamalaun, 1969, p. 1438) occurred during the last $8 \mathrm{~m} . y$. Mauritius is the oldest and consists mostly of alkali olivine basalt and some of its differentiates, known as the "Older Volcanic Series," which were erupted between 8 and 5 m.y. ago. Réunion has one 


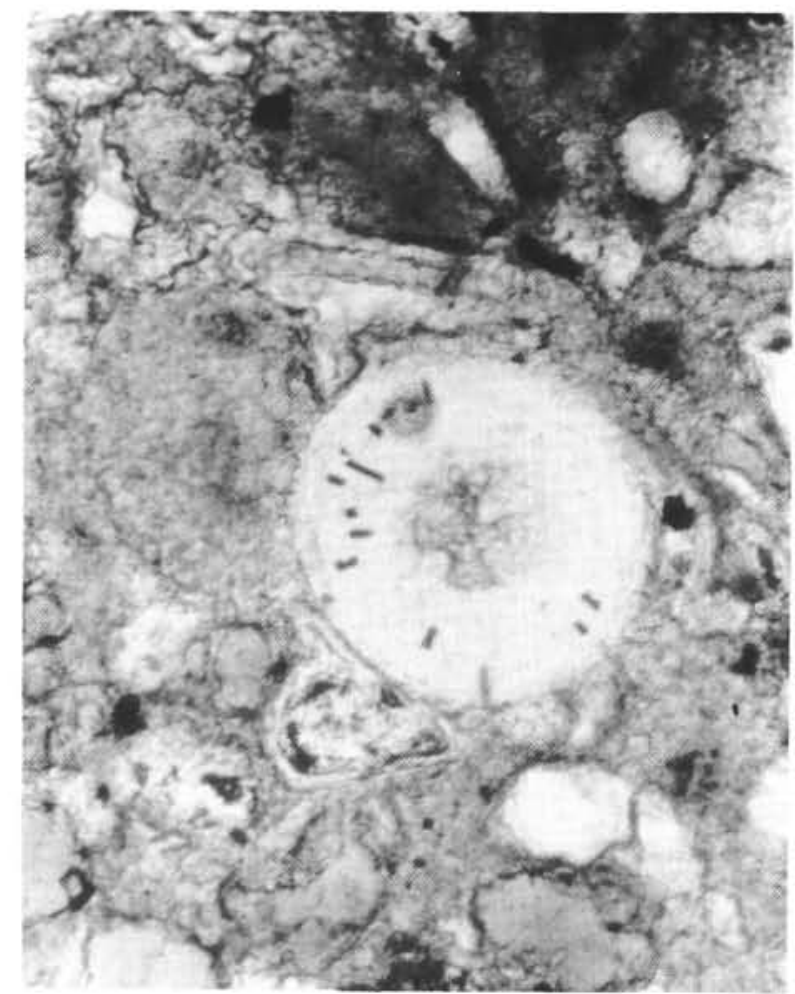

Figure 22. 249-24, CC. Photomicrograph of spherulitic structure in volcanic siltstone. Cristobalite spherulite may be replaced radiolarian or diatom. Field is about 0.6 $\mathrm{mm}$ in length.

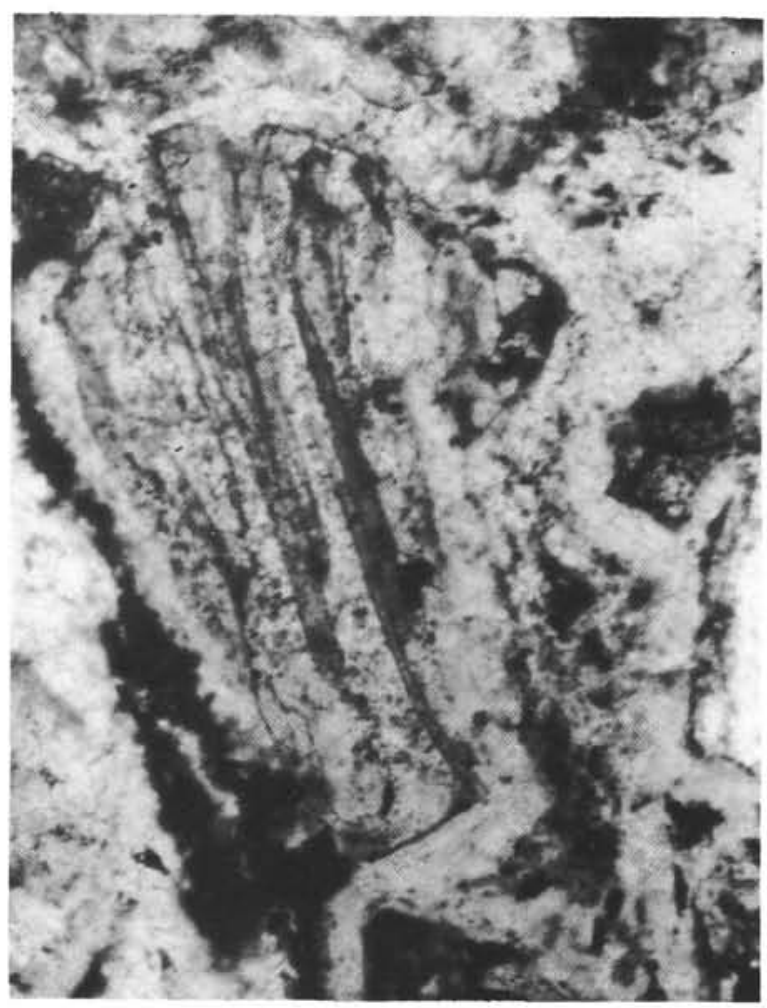

Figure 23. 249-25-2, 82-89 cm. Photomicrograph of glassy rock fragment (pumice) now replaced by montmorillonite and cristobalite(?). Field of view is about $0.6 \mathrm{~mm}$ in length.

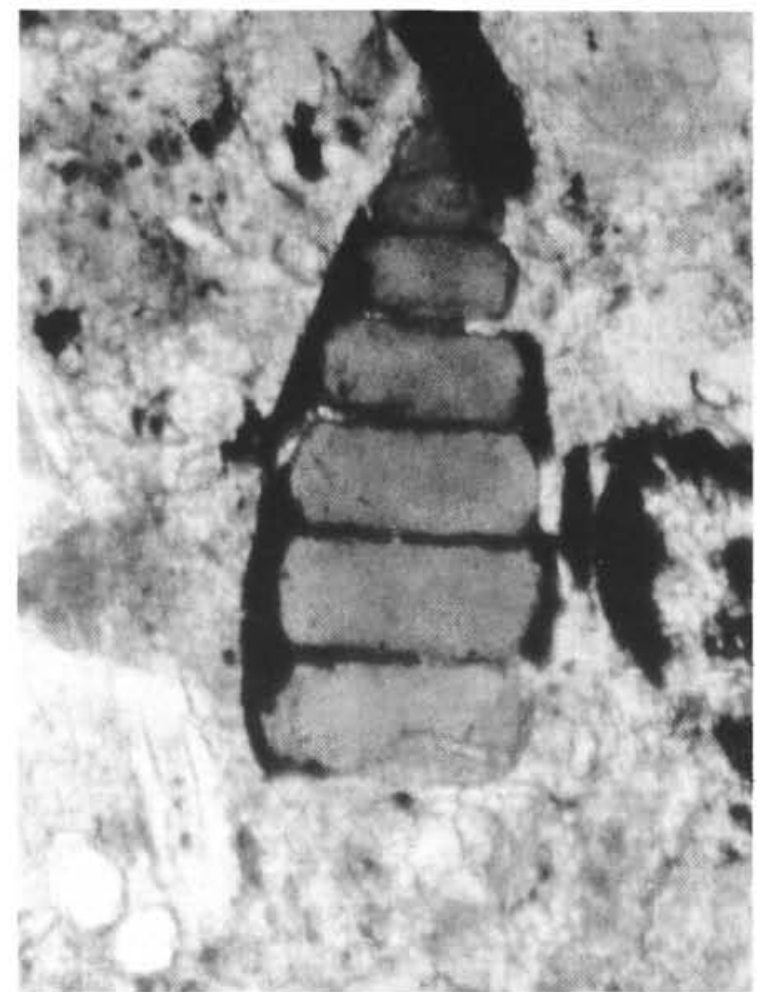

Figure 24. 249-26, CC. Photomicrograph of glauconitefilled radiolarian test in volcanic siltstone. Field is about $0.6 \mathrm{~mm}$ in length.

active volcano, Piton de la Fournaise, which erupts olivine basalt lava. However, according to Fisher et al. (1971), older volcanism along the "Chagos Fracture Zone" may have contributed some volcanic products in the Mascarene Plateau area ever since the Late Cretaceous.

\section{Western Indian Ocean Volcanism-Relation to Regional Volcanism}

\section{Introduction}

The geologic ages of basalt "basement" and volcanogenic sediments are needed in order to attempt any correlation of continental, island, and sea floor volcanic activities. Unfortunately, basalt was not recovered at all sites, and where it was recovered, several factors impeded precise dating. Among these are the following: (1) at two sites (245 and 248), the sediments directly above basalt were not recovered by coring; (2) at one site (240), the sediments were greatly mixed and good paleontologic dates could not be obtained; (3) at two sites (248 and 249), the sediments nearest basalt could not be dated because the fossils are either rare or absent; and (4) the basalts at three sites (239, 240 , and 249) are too deeply weathered to yield accurate radiometric ages.

The best dates (radiometric and paleontologic) of the basalts are given in Table 3. K-Ar dates were obtained for two basalts (Sites 245 and 248), where the overlying sediments were not recovered (see McKee, this volume). Schlich (this volume) has obtained new magnetic data for Sites 239 and 245 which indicate somewhat older ages than those previously calculated. He notes that Hole 239 was drilled on anomaly $31 / 32$ ( 74 m.y.) and that Hole 245 was drilled on anomaly $28 / 29$ ( $\sim 69$ m.y.). 


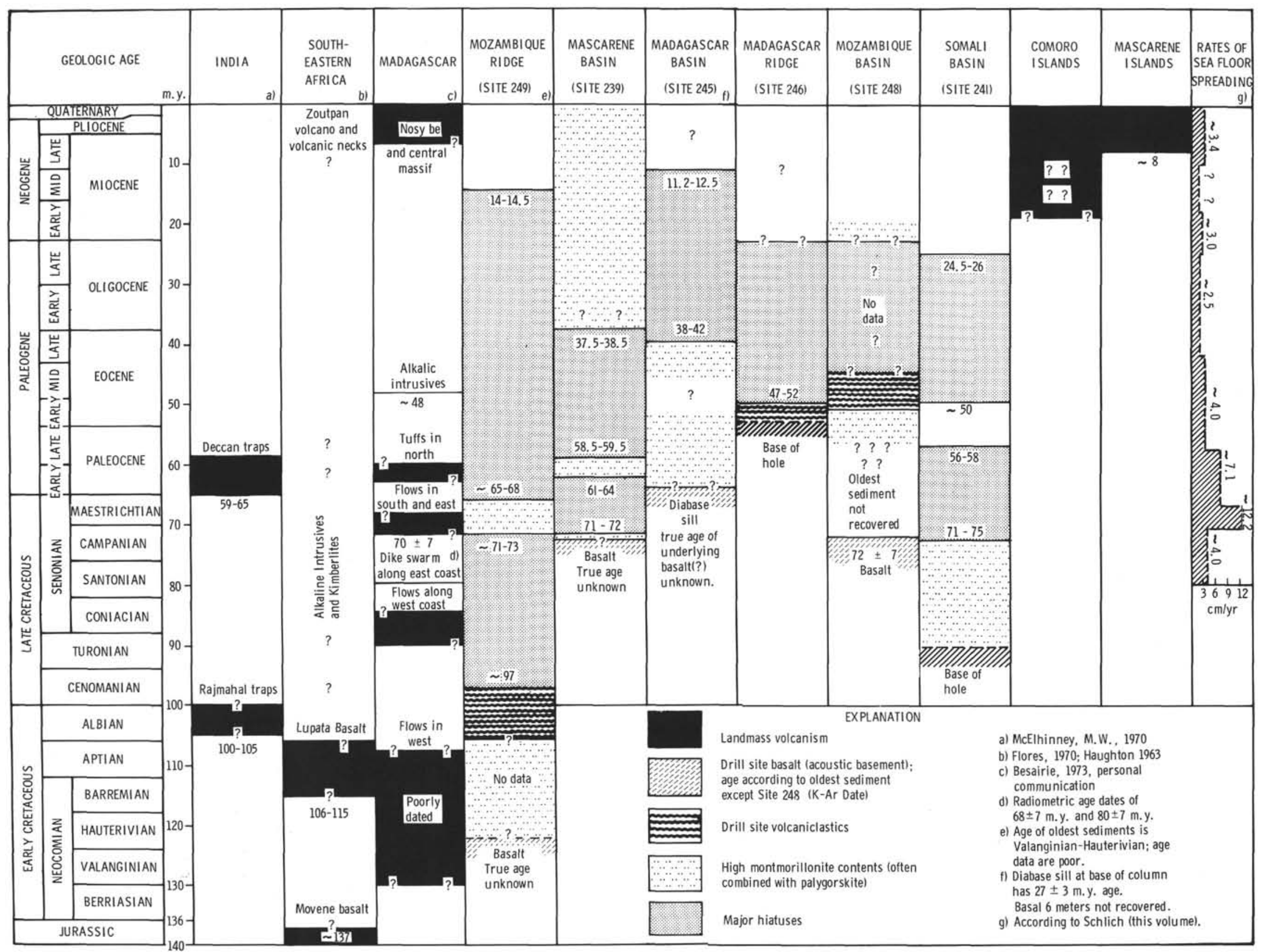

Figure 25. Diagram showing landmass, island, ocean floor volcanism and rates of sea floor spreading in the western Indian Ocean area. 
TABLE 2

Volcanism in South Africa (after Truter, 1949)

\begin{tabular}{|c|c|c|c|c|}
\hline Era or Group & $\begin{array}{l}\text { Period or } \\
\text { System }\end{array}$ & $\begin{array}{l}\text { Epoch or } \\
\text { Series }\end{array}$ & $\begin{array}{l}\text { Age or } \\
\text { Stage }\end{array}$ & $\begin{array}{c}\text { Volcanic Products } \\
\text { or Features }\end{array}$ \\
\hline \multirow{2}{*}{$\begin{array}{l}\frac{0}{0} \\
\text { N } \\
\text { ¿j } \\
0\end{array}$} & Quaternary (?) & & & Zoutpan volcano \\
\hline & Tertiary (?) & & & $\begin{array}{l}\text { Various breccia-filled } \\
\text { necks }\end{array}$ \\
\hline \multirow{6}{*}{ 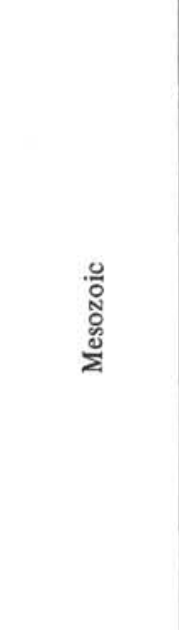 } & Cretaceous & & & $\begin{array}{l}\text { Plugs of melilite basalt } \\
\text { and necks of kimberlite }\end{array}$ \\
\hline & \multirow{6}{*}{ : } & \multirow{4}{*}{ Stromberg } & Drakensberg & $\begin{array}{l}\text { Flows of basalt, rhyolite, } \\
\text { and limburgite, and } \\
\text { volcanic necks }\end{array}$ \\
\hline & & & $\begin{array}{l}\text { Cave } \\
\text { Sandstone }\end{array}$ & \\
\hline & & & Red Bed & \\
\hline & & & Molteno & \\
\hline & & Beaufort & & \\
\hline 赵宫。 & & $\begin{array}{l}\text { Ecca } \\
\text { Dwyka }\end{array}$ & & \\
\hline
\end{tabular}

\section{Mascarene Basin (Site 239)}

The oldest sediments, overlying extrusive tholeiitic basalt, are late Campanian in age. Volcanism is shown mostly by a relatively high content of montmorillonite in the sediments.

It is probable that volcanic materials in the older (Cretaceous-middle Miocene) brown clay unit (Unit II) are associated with volcanism which accompanied the formation of the Central Indian Ridge and/or the development of the "Chagos Fracture Zone." Fisher et al. (1971, p. 559-560) indicate that during the Cretaceous through early Eocene interval, the then-active ridge crest trended east-west and a long transform fault, the "Chagos Fracture Zone," linked an ancient "Carlsberg Ridge" to its counterpart in the southeastern Indian Ocean. During the subsequent period of ocean floor evolution, magnetic anomalies 21 through 6 (early Eocene to early Miocene according to Heirtzler et al., 1968), spreading was very slow and the volcanic foundations of Chagos-Laccadive Ridge and of the southern part of the Mascarene Plateau (Saya de Malha to Mauritius) were extruded with the very slow widening of the "Chagos Fracture Zone."

Volcanic contributions in Unit I (middle MioceneQuaternary) are most likely related to the volcanism on nearby seamounts and islands in the Mascarene Island Group (Mauritius, Rodriguez, and Réunion). The oldest radiometric date from that island group is $8 \mathrm{~m} . \mathrm{y}$. on Mauritius (McDougall and Chamalaun, 1969, p. 1439); however, they suggest that older volcanic rocks might be present.

The age of the ocean floor at Site 239 (Campanian or older) may represent the age of a large part of the basalt floor in the Mascarene Basin because of the higher rate of spreading during that time interval. Volcanism in nearby Madagascar was particularly active during the Campanian according to Besairie (1973, personal communication). Flows in the southern part of the Morondava Basin (70 \pm 7 m.y.), the Androy "Massif" (70 \pm 7 m.y.), lava flows along the eastern coast ( $73 \pm 7$ m.y.), and dolerite dikes along the east coast north of Tamatave ( $68 \pm 7 \mathrm{~m} . \mathrm{y}$. and $80 \pm 7 \mathrm{~m} . \mathrm{y}$.) all testify to a time interval with major volcanism. The one radiometric date from the Mozambique Basin (Site 248) is 72 m.y., also Campanian. The contemporaneous volcanism in southern and eastern Madagascar and the basaltic extrusive activity in the Mascarene and Mozambique basins suggest a close relationship, and the Campanian probably was a time of major landmass and sea floor movements (13 $\mathrm{cm} / \mathrm{yr}$ according to Schlich, this volume) in the western Indian Ocean. 


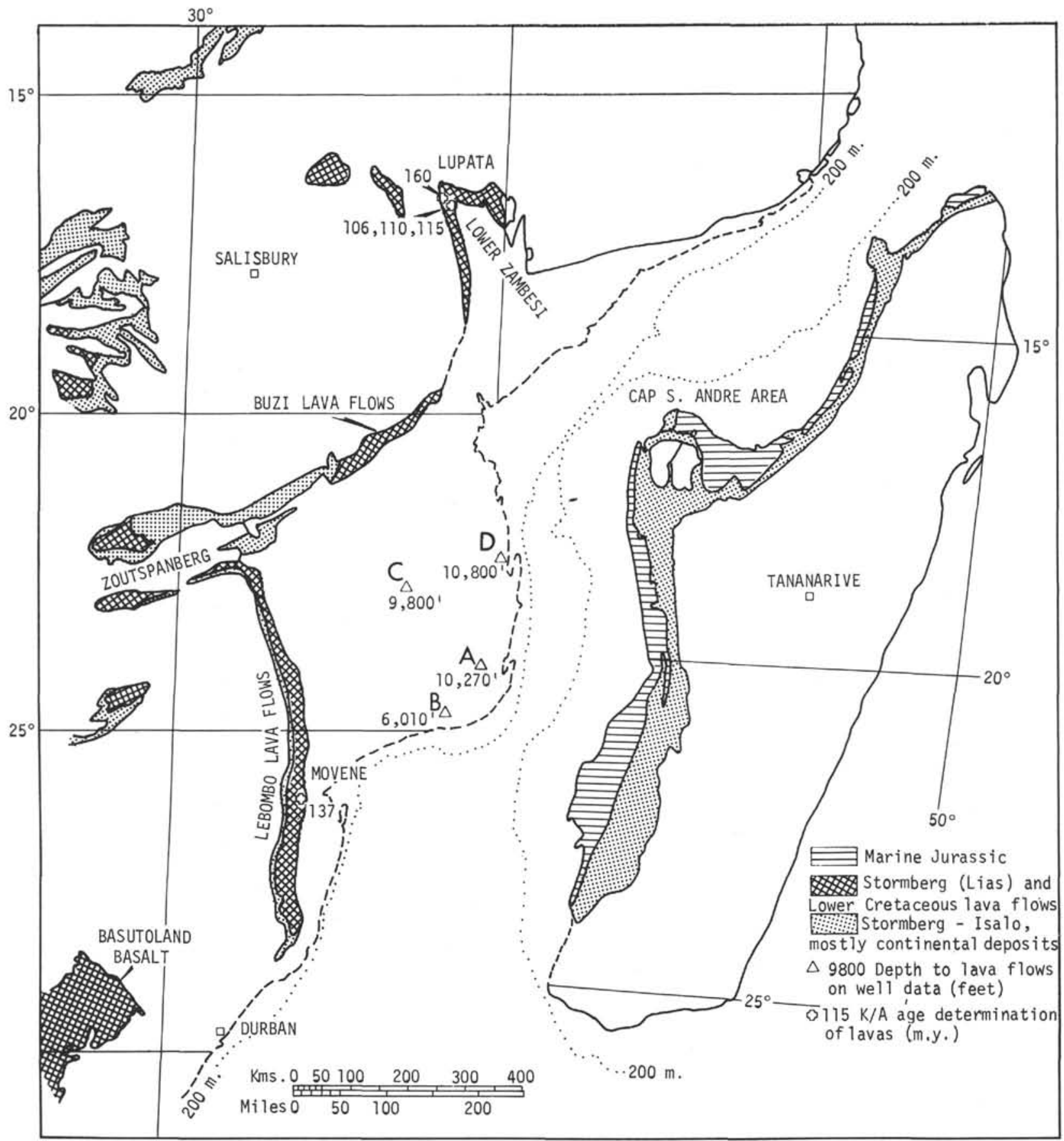

Figure 26. Distribution of known Karroo and Lower Cretaceous volcanics and of marine Jurassic strata (modified from Flores, 1970).

\section{Somali Basin (Sites 240 and 241)}

Because of the mixed nature of the sediments recovered at Site 240, few conclusions can be made concerning volcanism in the eastern Somali Basin. The tholeiitic basalt "basement" is early Eocene (about 52-54 m.y.) according to dates from overlying and included sediments.

Volcanic source terranes for pre-Miocene rocks at Site 241 are a problem. The younger, Miocene to Recent volcanic contributions, can be related to volcanism on Madagascar and the Comoro Islands and to erosion of the East Africa rift valley volcanics, which are no older than Miocene in Kenya (Baker, 1965, p. 82) and probably of the same age in Tanzania (Pallister, 1965, p. 88). Kent (1973, personal communication) states that there is no evidence of inland volcanism in eastern Africa earlier than Oligocene, which strongly suggests that East Africa was not the provenance of volcanic sediments older than Oligocene at 


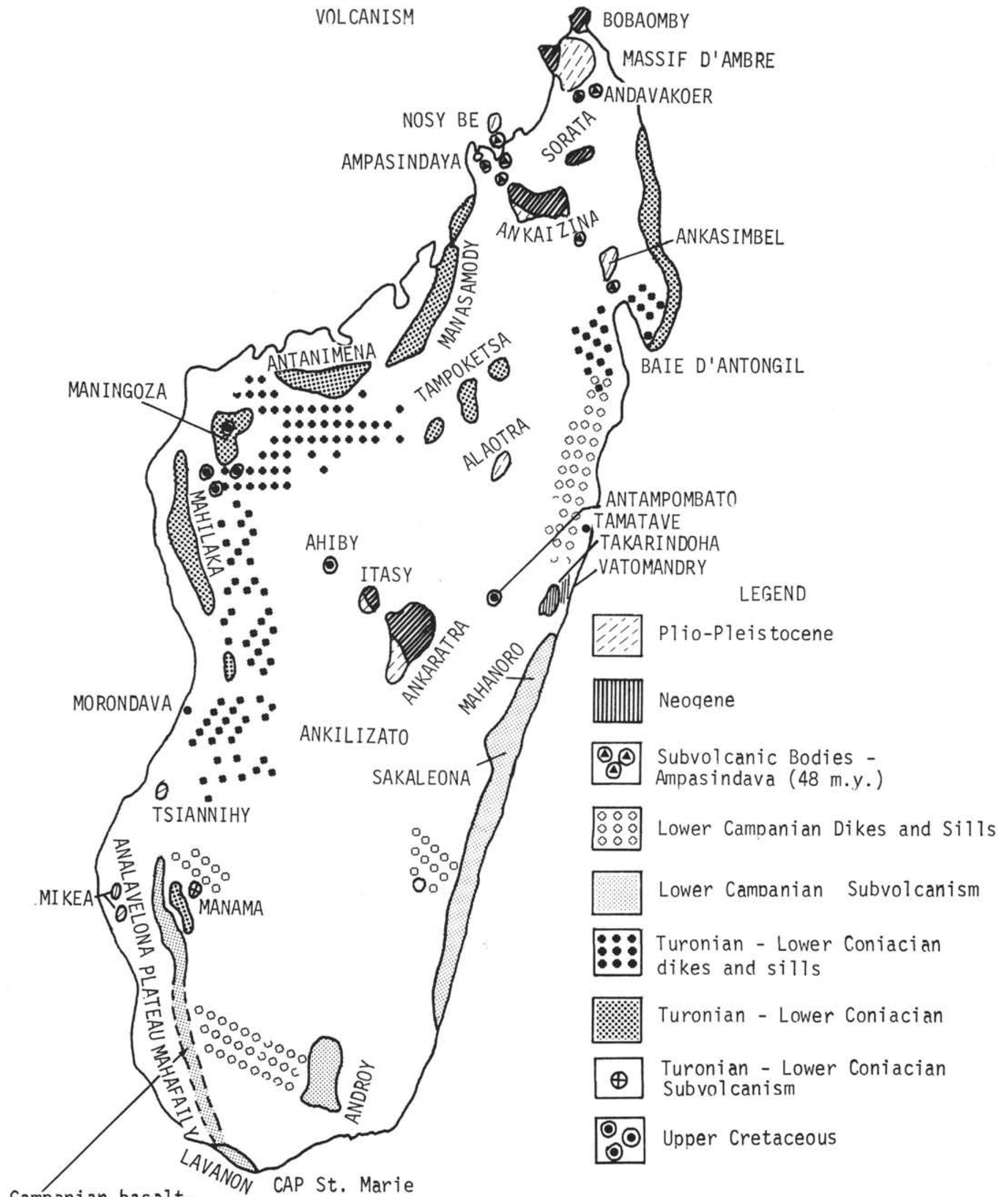

Campanian basalt, covered by Eocene sediments

Map by $H$. Besairie (1973, nersonal comunication)

Figure 27. Map showing Late Cretaceous to Recent volcanism in Madagascar prepared by Besairie (1973, personal communication). 
TABLE 3

Geologic Ages of "Basement" Basaltic Rocks, Leg 25, Western Indian Ocean

\begin{tabular}{cccl}
\hline $\begin{array}{c}\text { Site } \\
\text { Oldest Sediment }\end{array}$ & $\begin{array}{c}\text { Age of } \\
\text { K-Ar Age }{ }^{\mathrm{a}}\end{array}$ & \multicolumn{1}{c}{ Remarks } \\
\hline 239 & $71-72$ m.y. & - & $\begin{array}{l}\text { Age is late Campanian } \\
\text { according to nanno- } \\
\text { plankton. }\end{array}$ \\
240 & $52-54$ m.y. & -- & $\begin{array}{l}\text { Sediment greatly mixed. } \\
\text { Inclusion in basalt has } \\
\text { the same age. }\end{array}$ \\
245 & $62-65$ m.y. & $27 \pm 3$ m.y. & $\begin{array}{l}\text { Diabase sill for K-Ar } \\
\text { date. Oldest sediment } \\
\text { was not recovered. }\end{array}$ \\
249 & $50-55$ m.y. & $72 \pm 7$ m.y. & $\begin{array}{l}\text { Oldest sediment was } \\
\text { not recovered. } \\
\text { Neocomian (Valan- } \\
\text { 120-130 m.y. (?) }\end{array}$ \\
& -- & $\begin{array}{l}\text { ginian or Hauterivian) } \\
\text { recovered } ~ 10 \text { meters } \\
\text { above basalt. }\end{array}$ \\
\hline
\end{tabular}

${ }^{\mathrm{a}} \mathrm{McKee}$ (this volume).

Site 241. In the Cretaceous, India (and possibly Madagascar) was much closer to East Africa. Neocomian, Turonian, and Campanian volcanic terranes in western Madagascar and Albian volcanic rocks in India may have been the source terranes for the pre-Miocene volcanogenic sediments.

\section{Davie Ridge (Site 242)}

Davie Ridge, as indicated by sediments from Site 242, has been in the pelagic realm of sedimentation since at least the late Eocene. Volcanic components are shown only by the montmorillonite content and, consequently, are rare. The montmorillonite probably was transported to the site by ocean currents and winds from East Africa and Madagascar.

\section{Madagascar Basin (Site 245)}

Sediment characteristics at Site 245 reflect both horizontal and vertical movements of the sea floor. This part of the sea floor formed in earliest Paleocene (or latest Cretaceous) along the Central Indian Ridge and then moved laterally. Commencement of pelagic biogenic sedimentation was accompanied by hydrothermal (?) ferromanganoan additions and by volcanic activity, as shown by the abundant devitrified ash layers and the high montmorillonite content in the clay fractions. Significant amounts of volcanic products accumulated in the older nanno chalk sequence until about the middle Eocene; subsequently, the sea floor subsided and reached the CCD at about the same time as the first fine-grained nonvolcanic terrigenous sediment reached the site, probably from Madagascar. In the Miocene, horizontal movement continued slowly from the Indian Ridge systems. Volcanism since the middle Eocene has been relatively insignificant.
It can be concluded that most volcanism at Site 245 was associated with the mid-ocean ridge system. The abundance of ash layers in the older sediments suggests relatively shallow-water or island volcanism and dispersal by winds and ocean currents.

\section{Madagascar Ridge (Site 246)}

Basaltic pyroclastic sediments mark the early Eocene at Site 246. Associated benthonic foraminifera (Sigal, this volume) and ostracods (R.H. Benson, 1973, personal communication) indicate a shallow-water environment during that time and a subsequent deepening in the Miocene.

No known Eocene volcanic rocks crop out on either Madagascar or southeastern Africa. Some Eocene alkalic intrusives of gabbro, syenite, and granite do occur in the north part of Madagascar, but the long distance between that area and Site 246, plus the differences in rock types, suggest that the activities are unrelated. Fine-grained volcaniclastic sediments in the adjacent Mozambique Basin at Site 248 are of approximately the same age, which indicates a possible relationship.

The basaltic tuffs at Site 246 were deposited in shallow water and are the result of explosive volcanism either from islands or from shallow submarine volcanoes. Because acoustic "basement" was not reached (probably occurs at about $0.5 \mathrm{sec}$ doubletime [DT], where there is a high velocity layer with a $V p$ of $5 \mathrm{~km} / \mathrm{sec}$ ), it is not known what the complete volcanic record might be. However, the Eocene volcaniclastics apparently represent the last volcanic activity along Madagascar Ridge.

\section{Mozambique Basin (Site 248)}

Age of basalt "basement" at Site 248 is about $72 \neq 7$ m.y. (McKee, this volume), which places it in the Campanian, nearly contemporaneous with volcanic extrusions at Site 239 (age from oldest sediment) and with extensive volcanism in Madagascar. Sediments directly overlying the basalt (about $6 \mathrm{~m}$ ) were not recovered; the oldest paleontologically dated sediments are early Paleocene in age.

Early Eocene sediments in Unit II, and also some sediments in Unit III, show a strong volcanic influence. Montmorillonite percentages are high in the brown clay (Unit III). Both high iron and high manganese contents (Marchig and Vallier, this volume) in that unit suggest hydrothermal additions, thereby suggesting a possible association with an ancient spreading center. The overlying unit of gray-green volcanic clay and volcanic silty clay (Unit II) has high montmorillonite, palygorskite, and authigenic $\mathrm{SiO}_{2}$ mineral contents.

The volcanic sediments at Sites 246 and 248 are approximately contemporaneous, which suggests a relationship, not only in time, but possibly in space. Volcanoes on Madagascar Ridge probably yielded volcanic sediments to that ridge and to the adjoining Mozambique Basin during the early Eocene.

\section{Mozambique Ridge (Site 249)}

The basalt "basement" at Site 249 underlies Neocomian (Valanginian to Hauterivian) sediments. Its composition (Erlank et al., this volume) contrasts with the Cretaceous 
basalts on adjacent landmasses and the large vesicles, some more than $1 \mathrm{~cm}$ in diameter, suggest a shallow-water or subaerial origin. Lower Cretaceous sediments record abundant volcanic activity. Above the Lower Cretaceous sediments, evidence for volcanism is rare, and apparently the Mozambique Ridge has been volcanically inactive since the Early Cretaceous.

Sigal (this volume) suggests that the basalt might be correlative either with: (1) the Movene Basalt which overlies the Lebombo series and underlies the Domo Formation west of Lourenco Marques; (2) some of the Karroo Basalts of southeastern Africa; or (3) alternatively, they may be Neocomian in age and thereby unrelated to landmass volcanism. These alternatives all seem valid; any one might be the correct interpretation. There are no good paleontologic data from the overlying sediments at Site 249 , and the basalt is deeply weathered, which will make radiometric age dating difficult and probably inaccurate. Therefore, it is doubtful if the true age of the "basement" basalt can be established.

Volcanism had a significant effect on sedimentation throughout the Early Cretaceous sequence, culminating in Aptian-Albian pyroclastic activity. Explosive volcanism erupted basaltic tuffaceous sediments which were subsequently transported to the site, partly by subaqueous pyroclastic flows. At this time, the ridge must have been partly exposed, or the volcanoes erupted in relatively shallow water.

The volcanic sediments overlap, in time, reported volcanism in India (Rajmahal traps), southern Africa (Lupata Basalts), and possibly Madagascar (Neocomian flows in Morondava Basin). Because most paleontologic dating of the sediments in the Early Cretaceous at Site 249 is somewhat tenuous, and because the landmass rocks have not been extensively dated, precise correlations cannot be made. However, the correspondence of dates of major Early Cretaceous volcanism, on the landmasses and at Site 249 may not be merely coincidental. A working hypothesis, one that admittedly needs much more checking, is that these partly correlative Neocomian volcanic activities mark a major event in the history of the western Indian Ocean; possibly, the first major breakup of the continents.

\section{CORRELATION OF VOLCANISM AND SEA FLOOR-CONTINENT MOVEMENTS}

The history of a large part of the Indian Ocean basin, since the Late Cretaceous, is relatively well known. McKenzie and Sclater (1971), Sclater et al. (in press), and Sclater and Fisher (in preparation) provide a solid framework from which to work, particularly in the central and eastern parts. They speculate that the first movement from a spreading center occurred at about 100-105 m.y., when India began moving northward relative to Antarctica. However, no magnetic anomalies have been reported that are older than anomaly 33 ( 80 m.y.), which strongly suggests that reconstructions previous to $80 \mathrm{~m} . \mathrm{y}$. must rely on other data, such as best fits of continental margins, etc. Schlich (this volume), with new magnetic data, has established rates of sea floor movements (through anomaly 33) in the western Indian Ocean. He also has gathered all available data from geophysics and drilling in order to propose new explanations for the geologic history in that region.

Because magnetic anomalies older than 80 m.y. have not been identified in the Indian Ocean, any movements prior to that time are not recorded in the magnetic stripes which have proved so useful in reconstructing paleopositions of continents and oceans. Consequently, other methods for dating these movements would be desirable. Davies (1968) uses evidence of synchronous Eocene volcanic activity in India and the Seychelles Islands to demonstrate the possible time of rupture. Flores (1970) uses similar volcanic data to show when Madagascar and Africa were undergoing relative movement.

It is very possible that an understanding of the times of volcanism might lead to some hypotheses concerning continental break-up and major sea floor movements. An assumption made here is that most sea floor volcanism and some landmass volcanism are associated with tensional stresses. Therefore, similar ages of volcanic activity on landmasses that are believed to have been close together in the geologic past might signify times of major tensional stress. This would be strengthened if large parts of the ocean floor were formed by rapid sea floor spreading at the same time as the landmass volcanism.

Late Jurassic (Karroo) volcanism in southeastern Africa might mark the initial rifting of Gondwana. However, the correlation of Early Cretaceous volcanism in Africa, Madagascar India, and the Mozambique Ridge is most striking. The overlapping and, in part, time equivalency of the Lupata Basalt in East Africa, the Neocomian flow rocks in Madagascar, the Rajmahal Trap Basalts in India, and the basaltic volcanism at Site 249 suggest that Early Cretaceous (and Late Jurassic?) volcanism marks a major event in the evolution of the western Indian Ocean. This may be the time when India, Africa, and Madagascar first began breaking up.

The late Campanian (about 70-73 m.y.) apparently was the time of another major event. Extensive extrusive volcanism occurred in the eastern and southern parts of Madagascar, which corresponds to the time of a major change in the rate of sea floor spreading (Schlich, this volume). The Campanian also was the time when there was montmorillonite-rich sedimentation on Mozambique Ridge (Site 249) and the beginning of a major hiatus at Site 241. One must admit that these events may be purely coincidental and completely unrelated. However, they also might mark a second major event in the evolution of the western Indian Ocean.

The Eocene was another time of extensive volcanism in the western Indian Ocean. The basalt "basement" at Site 240 was extruded at about the same time as shallow alkalic intrusives were being emplaced in northern Madagascar and also at about the same time as explosive basaltic volcanism occurred on Madagascar Ridge (Site 246). Volcanic sediments were accumulating contemporaneously in the Mozambique Basin (Site 248). The significance of this Eocene event is not known, but it nearly coincides with the initiation of slower sea floor movements ( 55 m.y.), which is particularly well shown in the north central Indian Ocean Basin (McKenzie and Sclater, 1971) and in the south (Schlich, this volume). 


\section{CONCLUSIONS}

Volcanogenic sediments from most sites, drilled during Leg 25, are related to volcanism on landmasses (some of these sites have moved far from their original positions), to volcanic activity on oceanic islands, and to major events in spreading histories.

Specific conclusions are as follows:

1) Volcanism at Site 239 , in the Mascarene Basin, is related to volcanic events on Madagascar, to development of the "Chagos Fracture Zone," and to growth of the Mascarene Plateau and Mascarene Islands.

2) The volcanic sediments in the Late Cretaceous of Site 241 may be related to the volcanism in western Madagascar and possibly to volcanism in India.

3) At Site 245, in the Madagascar Basin, Paleocene volcanism is correlated with the exceptionally rapid sea floor movements from the Central Indian Ridge. $\mathrm{Fe} / \mathrm{Mn}$ sediments at the site also suggest a relationship to mid-ocean ridge volcanism.

4) Sites 246 (Madagascar Ridge) and 248 (Mozambique Basin) have Eocene volcanic sediments, which probably are related to volcanic activity on the Madagascar Ridge and to changes in the rate and direction of spreading.

5) The "basement" basalt at Site 248 is about Campanian in age (72 m.y.) which correlates well with a time of rapid sea floor movement and the age of extensive volcanism in Madagascar.

6) Site 249 (Mozambique Ridge) volcanic sediments are of Early Cretaceous age, and may be indirectly related to volcanism that occurred in India, eastern Africa, and Madagascar.

Contemporaneous volcanism, as recorded by the volcanic sediments and the volcanic accumulations on continents and islands, may mark major tensional tectonic events in the western Indian Ocean. If this is true, then the major break-up of Gondwana took place in the latest Jurassic-Neocomian time interval when voluminous basalt was extruded in Africa and Madagascar. Another major event, in the Campanian (70-73 m.y. ago), marks the time of a major event in sea floor evolution when an important change in the rate of movement occurred. Volcanic activity in the Eocene also signifies a time of sea floor adjustment.

\section{ACKNOWLEDGMENTS}

I am particularly grateful to the scientific staff who served with me on the Glomar Challenger during Leg 25 of the Deep Sea Drilling Project. I appreciate the comments and suggestions of geologists who read an early draft of this manuscript. These include: Paul Robinson, University of California, Riverside, California; Alan Moore, University of Capetown, Rondebosch, South Africa; Peter Kent, Nottingham, England; Lucien Leclaire, Museum National D'Histoire Naturelle, Paris, France; and H. Besairie, Tananarive, Madagascar. I also thank W. Steichen for reviewing the manuscript and for suggesting many significant improvements.

\section{REFERENCES}

Arrhenius, G., 1963. Pelagic sediments. In The Sea, Hill, M. N. (Ed.): New York (Interscience Publications), v. 3, p. $655-727$.
Baker, B. H., 1965. The rift system in Kenya. In East African rift system: UMC/UNESCO Seminar East African Rift System, Mairobi, April 12-17, 1965. Rept., Nairobi (University College), p. 82-85.

Berger, W. H. and von rad, U., 1972. Cretaceous and Cenozoic sediments from the Atlantic Ocean. In Hayes, D. E., Pimm, A. C., et al., Initial Reports of the Deep Sea Drilling Project, Volume XIV: Washington (U. S. Government Printing Office), p. 787-955.

Besairie, Henri, 1972. Géologie de Madagascar, I. Les Terrains Sedimentaires: An. Géol. de Madagascar, pt.35, Tananarive, Madagascar, pp. 463.

Blant, G., 1973. Structure et paléogéographie du littoral méridional et oriental de l'A frique. In Blant, G. (Ed.), Sedimentary Basins of the African Coasts, pt. 2: south and east coast: Paris (Assoc. African Geol. Surveys), p. 193-233.

Bonatti, E., 1972. Authigenesis of minerals-Marine. In The Encyclopedia of Geochemistry and Environmental Sciences, Fairbridge, R. W. (Ed.), New York (Van Nostrand Reinhold Company), p. 52.

Bonatti, E. and Joensuu, O., 1968. Palygorskite from Atlantic deep sea sediments: Am Mineral., v. 53, p. 975-983.

Davies, D., 1968. When did the Seychelles leave India?: Nature, v. 220, p. 1225-1226.

Fisher, R. L., Sclater, J. G., and McKenzie, Dan, 1971. Evolution of the Central Indian Ridge, western Indian Ocean: Geol. Soc. Am. Bull., v. 82, p. 553-562.

Flores, Giovanni, 1970. Suggested origin of the Mozambique Channel: Geol. Soc. Africa Trans., v. 73, pt. 1, p. 1-16.

Frankel, J. J., 1960. Late Mesozoic and Cenozoic events in Natal, South Africa: N. Y. Acad. Sci. Trans., ser. 2, v. 22 , p. $565-577$.

Griffin, J. J., Windom, Herbert, and Goldberg, E. D., 1968. The distribution of clay minerals in the world ocean: Deep Sea Res., v. 15, p. 433-459.

Hathaway, J. C. and Sachs, P. L., 1965. Sepiolite and clinoptilolite from the Mid-Atlantic Ridge: Am. Mineral., v. 50, p. 852-867.

Hathaway, J. C., McFarlin, P. F., and Ross, D. A., 1970. Mineralogy and origin of sediments from drill holes on the continental margin off Florida: U. S. Geol. Survey Prof. Paper 581-E, 26 pp.

Haughton, S. H., 1963. The stratigraphic history of Africa south of the Sahara: Edinburgh and London, (Oliver and Boyd), 365 pp.

Heirtzler, J. R., Dickson, D. O., Herron, E. M., Pitman, W. C., III, and Le Pichon, X., 1968. Marine magnetic anomalies, geomagnetic field reversal, and motions of the ocean floor and continents: J. Geophys. Res., v. 73, p. 2119-2136.

Lancelot, Yves, 1973. Chert and silica diagenesis in sediments from the central Pacific. In Winterer, E. L., Ewing, J. I., et al., Initial Reports of the Deep Sea Drilling Project, Volume XVII: Washington (U. S. Government Printing Office), p. 377-405.

Lynn, D. C. and Bonatti, E., 1965. Mobility of manganese in diagenesis of deep sea sediments: Marine Geol., v. 3, p. $457-475$.

McDougall, I. and Chamalaun, F. H., 1969. Isotopic dating and geomagnetic studies on volcanic rocks from Mauritius, Indian Ocean: Geol. Soc. Am., Bull. v. 80, p. 1419-1442.

McElhinney, M. W., 1970. Formation of the Indian Ocean: Nature, v. 288 , p. $977-979$. 
McKenzie, F.T., and Garrels, R. M., 1965. Silicates: reactivity with sea water: Science, v. 150, p. 57-58.

McKenzie, Dan and Sclater, J. G., 1971. The evolution of the Indian Ocean since the Late Cretaceous: Roy. Astron. Soc. Geophys. J., v. 24, p. 1-92.

Millot, G., Paquet, H., and Reullan, A., 1969. Néoformation d'attapulgite dans les sols á carapaces calcaires de la Basse Monlonya (Moroc Oriental): Acad. Sc. (Paris) Comptes rendus, v. 268 (ser. D), p. 2771-2773.

Pallister, J. W., 1965. The rift system in Tanzania. In East African rift system: UMC/UNESCO Seminar East African Rift System, Nairobi, April 12-17, 1965, Rept., Nairobi (University College), p. 86-86.

Sclater, J. G, and Fisher, R. L. in preparation. The evolution of the East Central Indian Ocean, with emphasis on the tectonic setting of the Ninetyeast Ridge.

Sclater, J. G., von der Borth, Chris, Veevers, J., Hekinian, Roger, Thompson, R. W., Pimm, A. C., McGowran,
Brian, Gartner, Stefan, Jr., and Johnson, D. A., in press. Regional synthesis of the deep sea drilling results from Leg 22 in the eastern Indian Ocean. In Initial Reports of the Deep Sea Drilling Project, Volume XXII: Washington (U. S. Government Printing Office.).

Siever, R. and Kastner, M., 1967. Mineralogy and petrology of some Mid-Atlantic Ridge sediments: Marine Res., v. 25 , p. $263-278$.

Tanner, P. W. G., 1973. Orogenic Cycles in East Africa: Geol. Soc. Am. Bull., v. 84 , p. $2839-2850$.

Truter, F. C., 1949. A review of volcanism in the geological history of South Africa (anniversary address by the president): Geol. Soc. S. Africa Trans., v. 52, p. 29-88.

Zemmels, I., and Cook, H. E., 1973. X-ray mineralogy studies of selected samples from the sea floor of the northeast Atlantic and Mediterranean Sea. In Ryan, W. B. F., Hsu, K. J., et al., Initial Reports of the Deep Sea Drilling Project, Volume XIII: Washington (U. S. Government Printing Office), p. 605-665. 